\title{
Hypothalamic and brainstem neuronal circuits controlling homeostatic energy balance
}

\author{
Marc Schneeberger ${ }^{1,2,3}$, Ramon Gomis ${ }^{1,2,3}$ and Marc Claret ${ }^{1,3}$ \\ ${ }^{1}$ Diabetes and Obesity Research Laboratory, Institut d'Investigacions Biomèdiques August Pi i Sunyer (IDIBAPS), \\ 08036 Barcelona, Spain \\ ${ }^{2}$ Department of Endocrinology and Nutrition, School of Medicine, Hospital Clínic, University of Barcelona, 08036 \\ Barcelona, Spain \\ ${ }^{3}$ Centro de Investigación Biomédica en Red de Diabetes y Enfermedades Metabólicas Asociadas (CIBERDEM), 08036 \\ Barcelona, Spain
}

\author{
Correspondence \\ should be addressed \\ to $\mathrm{M}$ Claret \\ Email \\ MCLARET@clinic.ub.es
}

\begin{abstract}
Alterations in adequate energy balance maintenance result in serious metabolic disturbances such as obesity. In mammals, this complex process is orchestrated by multiple and distributed neuronal circuits. Hypothalamic and brainstem neuronal circuits are critically involved in the sensing of circulating and local factors conveying information about the energy status of the organism. The integration of these signals culminates in the generation of specific and coordinated physiological responses aimed at regulating energy balance through the modulation of appetite and energy expenditure. In this article, we review current knowledge on the homeostatic regulation of energy balance, emphasizing recent advances in mouse genetics, electrophysiology, and optogenetic techniques that have greatly contributed to improving our understanding of this central process.
\end{abstract}

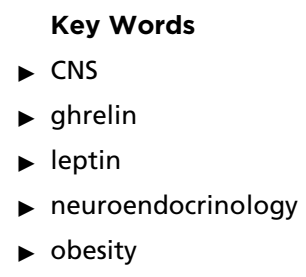

Journal of Endocrinology (2014) 220, T25-T46

\section{Introduction}

The regulation of appetite and body weight is an intricate process controlled by redundant and distributed neural systems that integrate a myriad of cognitive, hedonic, emotional, and homeostatic cues to precisely regulate systemic energy balance through behavioral, autonomic, and endocrine outputs. These sophisticated biological programs are influenced by multiple factors, including environmental, genetic, and epigenetic mechanisms. The immense complexity of these systems illustrates the biological importance of adequate nutrient and energy balance, a process that has been evolutionarily conserved and refined to guarantee appropriate adiposity levels. Despite the precision of these systems in matching energy demand with energy expenditure, contemporary, and lifestyle factors are the main causes of the prevailing obesity epidemics. The present review attempts to summarize current understanding of the anatomy, neurochemistry, functions, and interactions of relevant neural circuits involved in the homeostatic regulation of energy balance.

\section{The homeostatic system: hypothalamus and brainstem}

The hypothalamus: neuronal anatomy, nuclei, and neuropeptides

Seminal lesioning studies conducted in rodents during the 1940s and 1950s highlighted the importance of the hypothalamus in the regulation of body weight. Since then, extensive experimental evidence and extraordinary 
progress in understanding the neurobiology of obesity have firmly established the mediobasal hypothalamus as a fundamental nexus in the neuronal hierarchy controlling whole-body energy balance. The hypothalamus is constituted by distinct hypothalamic nuclei including the arcuate nucleus (ARC), the paraventricular nucleus (PVN), the lateral hypothalamic area (LHA), the dorsomedial nucleus (DMN), and the ventromedial nucleus (VMN).

Arcuate nucleus The ARC is a very important area of the CNS involved in the control of energy homeostasis. It is located below the $\mathrm{VMN}$, on both sides of the third ventricle, and immediately adjacent to the median eminence (ME). This area has a semi-permeable blood-brain barrier (BBB; Broadwell \& Brightman 1976), and thus it is strategically positioned to sense hormonal and nutrient fluctuations in the bloodstream. In the ARC, there are at least two major populations of neurons controlling appetite and energy expenditure: i) a subset of neurons that coexpress orexigenic neuropeptide $\mathrm{Y}$ (NPY) and agoutirelated peptide (AGRP) and ii) a population of neurons that coexpress the anorexigenic neuropeptides cocaine- and amphetamine-regulated transcript (CART (CARTPT)) and $\alpha$-melanocyte-stimulating hormone $(\alpha-\mathrm{MSH}$, a product of proopiomelanocortin (POMC) processing). These two populations of neurons (hereafter referred to as AgRP and POMC respectively), together with downstream target neurons expressing the melanocortin receptor 4 (MC4R) and MC3R, constitute the central melanocortin system. This neuronal circuit is crucial for sensing and integrating a number of peripheral signals allowing for a precise control of food intake and energy expenditure (see section 'ARC neuronal circuits: POMC, AgRP, and RIPCre neurons').

NPY is widely expressed throughout the CNS, but it is most densely localized in the ARC in the hypothalamus (Gehlert et al. 1987). The expression and release of ARC NPY respond to changes in energy status, being reduced under feeding conditions and increased under fasting conditions (Beck et al. 1990, Kalra et al. 1991). Increasing NPY tone pharmacologically results in hyperphagia and reduced thermogenesis of brown adipose tissue (BAT), associated with diminished activity of the thyroid axis (Clark et al. 1984, Stanley et al. 1986, Egawa et al. 1991). Although NPY acts at five different receptors (Y1, Y2, Y3, Y4, and y6), genetic and pharmacological studies suggest that postsynaptic Y1 and Y5 receptors mediate the effects of NPY on positive energy balance (Nguyen et al. 2012, Sohn et al. 2013).

AGRP is also an orexigenic neuropeptide that is exclusively expressed in the ARC, where it colocalizes with NPY and the neurotransmitter $\gamma$-aminobutyric acid (GABA; Broberger et al. 1998, Cowley et al. 2001). The central administration of AGRP or its genetic overexpression stimulates food intake, reduces energy expenditure, and causes obesity (Graham et al. 1997, Ollmann et al. 1997, Small et al. 2003). Interestingly, lasting orexigenic effects (over days) after AGRP delivery have been reported (Hagan et al. 2000).

AgRP neurons express receptors for peripheral hormonal signals such as insulin (Marks et al. 1990), leptin (Elmquist et al. 1998), and ghrelin (Willesen et al. 1999). These neurons send projections mainly into the PVN, DMN, and LHA. Despite the well-documented effects of NPY and AGRP as positive modulators of energy balance, genetic studies have yielded conflicting results. For example, Agrp- and Npy-knockout (KO) mice failed to exhibit alterations in body weight or feeding behavior (Palmiter et al. 1998, Qian et al. 2002, Corander et al. 2011). However, the ablation of AgRP neurons in adults leads to uncontrolled anorexia but is well tolerated in neonates, indicating the existence of developmental compensations (Bewick et al. 2005, Gropp et al. 2005, Luquet et al. 2005).

CART is widely expressed in the brain, but it is particularly abundant in the hypothalamus, and it colocalizes (>95\%) with POMC in the ARC (Elias et al. 1998). Its expression is enhanced under feeding conditions and reduced under fasting conditions (Kristensen et al. 1998), and it has been shown that i.c.v. infusion of CART inhibits food intake, while antibodies against CART reverse this effect (Kristensen et al. 1998). Furthermore, CART also stimulates the thermogenesis of BAT (Kotz et al. 2000). However, Cartpt-deficient mice exhibit no alterations in food intake or body weight when fed with a standard diet, but develop obesity after being fed with a high-fat diet (HFD; Asnicar et al. 2001). Interestingly, and contrary to the prevailing anorexigenic view, other studies have shown that under certain experimental conditions CART may stimulate food intake (Abbott et al. 2003, Kong et al. 2003). Collectively, results regarding the effects of CART on feeding behavior are inconclusive and indicate anatomically divergent roles for this neuropeptide.

POMC is a prohormone precursor that is cleaved into several bioactive peptides in the hypothalamus, including $\alpha$-MSH, which exerts potent anorexigenic effects by binding to MC3R and MC4R (Mercer et al. 2013). The levels of Pomc transcripts and $\alpha$-MSH are increased under feeding conditions and decreased under fasting conditions (Schwartz et al. 1997). The i.c.v. administration of $\alpha$-MSH or its delivery into the PVN suppresses food intake and

Published by Bioscientifica Ltd 
reduces body weight (Poggioli et al. 1986, Wirth et al. 2001). Genetic manipulation of the Pomc gene leading to the overexpression of $\alpha$-MSH has been shown to cause anti-obesity effects in genetic and diet-induced obesity (DIO) models (Mizuno et al. 2003, Savontaus et al. 2004, Lee et al. 2007). A key role for POMC in whole-body energy homeostasis is evident, as mice lacking Pomc, melanocortin peptides, or POMC neurons develop obesity (Yaswen et al. 1999, Gropp et al. 2005, Xu et al. 2005a, Smart et al. 2006). Furthermore, mutations in the POMC gene have been reported to be associated with morbid obesity in humans (Krude et al. 1998, Lee et al. 2006). GABAergic and glutamatergic subpopulations of POMC neurons have been described, although their functional roles are unclear (Mercer et al. 2013).

Paraventricular nucleus The PVN is located in the anterior hypothalamus, just above the third ventricle, and expresses high levels of MC3R/MC4R. It receives innervation not only from the AgRP and POMC neurons of the ARC but also from extrahypothalamic regions such as the nucleus of the tractus solitarius (NTS). The PVN is an important integration site involved in whole-body energy homeostasis, as shown by the diverse afferent inputs and its high sensitivity to the administration of endogenous neuropeptides involved in the regulation of food intake such as NPY, AGRP, and $\alpha$-MSH, among others (Stanley et al. 1986, Kim et al. 2000). Part of these effects are mediated by a subset of neurons that express thyrotropin-releasing hormone (TRH), which are activated by $\alpha$-MSH and inhibited by AGRP (Fekete et al. 2000, 2004). Another relevant subset of neurons express corticotrophinreleasing hormone $(\mathrm{CRH})$, which are directly involved in the control of energy balance through AGRP innervation or indirectly through the regulation of adrenal glucocorticoids controlling the expression of POMC (Richard $\&$ Baraboi 2004).

Lateral hypothalamus area The LHA plays a critical role in the mediation of orexigenic responses, a function that can be significantly attributed to orexin and melaninconcentrating hormone $(\mathrm{MCH})$ neurons. Orexin neurons produce orexin A and orexin B from prepro-orexin, the expression of which is increased under fasting conditions (Sakurai et al. 1998). The central administration of orexins not only increases food intake (Sakurai et al. 1998, Dube et al. 1999), but also promotes behavioral responses to food reward and increases arousal (Cason et al. 2010). Orexin neurons project not only within the LHA, ARC, PVN, and NTS, but also into other regions involved in additional physiological functions such as body temperature and wakefulness control, among others (Peyron et al. 1998). Similarly, fasting enhances the expression of Mch (Pmch) mRNA and its i.c.v. administration or genetic overexpression causes an orexigenic output (Qu et al. 1996, Ludwig et al. 2001). Conversely, mice with reduced $\mathrm{MCH}$ tone or disruption of the $\mathrm{MCH} 1$ receptor are lean (Marsh et al. 2002).

Dorsomedial nucleus The DMN is involved in a range of physiological processes, including appetite, thermoregulation, stress, and circadian rhythms. It receives projections from most of the hypothalamic nuclei, especially the ARC, and sends projections into the PVN and LHA. A number of neuropeptides (such as NPY and CRH) as well as receptors for peptides involved in the control of appetite and energy balance are expressed within the DMN. Increased expression of NPY in the DMN has been reported in several rodent models of obesity (Guan et al. 1998, Bi et al. 2001), and it may play a significant role in the regulation of thermogenesis and the development of DIO (Chao et al. 2011).

Ventromedial nucleus The AgRP and POMC neurons of the ARC project into the VMN. In turn, VMN neurons project into hypothalamic and extrahypothalamic areas such as the brainstem (Cheung et al. 2013). Lasermicrodissection studies have identified a number of VMN-enriched genes (Segal et al. 2005), including steroidogenic factor 1 ( $S f 1$ (Nr5a1)), which has been directly implicated in the development of the VMN (Parker et al. 2002, Davis et al. 2004). SF1-expressing neurons play significant roles in the control of energy balance, as demonstrated by the metabolic phenotypes of conditional KO mice (Bingham et al. 2008, Zhang et al. 2008, Kim et al. 2011). Another abundantly expressed protein in the VMN is the brain-derived neurotrophic factor (BDNF). The lack of $B D N F$ or its receptor (TRKB (NTRK2)) leads to hyperphagia and obesity in humans and mice (Lyons et al. 1999, Yeo et al. 2004). In contrast, the central or peripheral administration of BDNF results in the loss of body weight and reduction in food intake through MC4R signaling (Xu et al. 2003). The VMN also plays a key role in the regulation of thermogenesis (Lopez et al. 2010, Kim et al. 2011, Martinez de Morentin et al. 2012, Whittle et al. 2012).

\section{The brainstem}

Brainstem neurons make key contributions to the control of energy balance by processing energy status information

Published by Bioscientifica Ltd 
at four different levels: i) by sensing circulating metabolites and hormones released by peripheral organs; ii) by receiving vagal inputs from the gastrointestinal (GI) tract; iii) by receiving neuronal inputs from midbrain and forebrain nuclei that also detect and integrate energyrelated signals; and iv) by projecting into local brainstem circuits and other regions of the brain to provide information that will be integrated by these neurons to control energy balance. Within the brainstem, the dorsal vagal complex (DVC) is a key module for the integration of energy-related cues by relying peripheral signals through vagal afferents and projecting into the hypothalamus and other relevant areas. The DVC comprises the dorsal motor nucleus of the vagus, the NTS, and the area postrema (AP), which has an incomplete $\mathrm{BBB}$ and therefore it is accessible to peripheral signals.

The brainstem is constituted by heterogeneous populations of neurons, with distinct biophysical and neurochemical properties, that express appetite-modulatory neuropeptides such as tyrosine hydroxylase $(\mathrm{TH})$, proglucagon, CART, GABA, NPY, BDNF, and POMC, among others. These neurons also express a variety of receptors mediating the effects of some of the aforementioned neuropeptides, indicating the existence of local circuits that contribute to the regulation of ingestive behaviors. In addition, receptors for a number of circulating hormones such as leptin, ghrelin, glucagon-like peptide 1 (GLP1), and cholecystokinin (CCK) have been described in brainstem neurons or in vagal afferent projections to brainstem areas.

Vagal signaling from the GI tract is an important afferent to the NTS, conveying information about luminal distension, nutritional content, and locally produced peptides via glutamate neurotransmission (Travagli et al. 2006). This vagal sensory and hormonal information will be assimilated by second-order NTS neurons that project into the hypothalamus and other basal forebrain areas to elaborate precise outputs. The significance of the vagus nerve transmission has been demonstrated through a number of manipulations to eliminate or enhance its activity. For example, chronic or acute vagus nerve stimulation in rats leads to a reduction in body weight and food intake, indicating that direct vagal afferent interventions influence feeding behavior (Krolczyk et al. 2001, Gil et al. 2011). Vagal signaling also plays important roles in the regulation of meal size and duration (Schwartz et al. 1999).

The NTS receives inputs from descending projections from the hypothalamus. In particular, ARC POMC neurons project into the NTS, where high expression levels of MC4R have been reported (Kishi et al. 2003).
In addition to the release of $\alpha$-MSH from ARC POMC neurons, the NTS also receives melanocortin agonist signals from a local population of $\sim 300$ POMC neurons (around $10 \%$ of the total number of POMC neurons; Palkovits \& Eskay 1987). Recent pharmacogenetic studies have shown different functions and time scale effects of ARC and NTS POMC neurons on food intake and metabolism (Zhan et al. 2013). The importance of this neuronal circuit is further demonstrated by hindbrain MC4R agonist delivery, which leads to a reduction in food intake and an increase in energy expenditure, whereas MC4R antagonism drives the opposite effect (Williams et al. 2000, Skibicka \& Grill 2009b). MC4Rs in the NTS seem to mediate not only the satiation effects of CCK (Fan et al. 2004), but also the anorexigenic effects of hypothalamic and brainstem leptin signaling (Skibicka \& Grill 2009a, Zheng et al. 2010).

The NTS also receives descending projections from orexin and $\mathrm{MCH}$ neurons located in the LHA (Ciriello et al. 2003), and the delivery of orexin A into the hindbrain increases food intake (Parise et al. 2011). The orexigenic nature of the LHA and the anatomical connection with the NTS indicated that this system may serve as a mechanism to limit the satiety signals from the GI tract.

Another hypothalamic nucleus sending projections into the NTS is the PVN (Sawchenko \& Swanson 1982, Luiten et al. 1985). The PVN-brainstem pathway plays a significant role in the regulation of energy balance, as contralateral disruption of PVN output and NTS input causes hyperphagic obesity (Kirchgessner \& Sclafani 1988). Different areas of the brainstem show TRH-positive fibers, and evidence indicates that TRH is involved in the brainstem regulation of energy homeostasis by integrating endocrine and vagal-sympathetic responses (Ao et al. 2006, Zhao et al. 2013).

\section{Hormonal signals involved in energy homeostasis control}

\section{Peripheral adiposity signals: leptin and insulin}

The discovery of leptin, the product of the $O b$ gene, in 1994 (Zhang et al. 1994) opened a new dimension in the field of the central regulation of energy balance. Leptin is an anorexigenic adipose tissue-derived hormone that circulates in proportion to fat mass (Considine et al. 1996). It reaches the CNS through a saturable transport system and conveys information about the energy status of the organism. There are multiple leptin receptor (LEPR) isoforms, with the long form (LEPRb) being essential for

Published by Bioscientifica Ltd 
the effects of leptin. The lack of leptin or $L E P R b$ in both rodents and humans causes a phenotype characterized by hyperphagia, reduced energy expenditure, and severe obesity (Halaas et al. 1995, Chen et al. 1996, Montague et al. 1997, Clement et al. 1998). Most obese patients exhibit a state of leptin resistance, which is the inability of high circulating leptin levels to exert central anorexigenic actions, which precludes the use of leptin as a therapeutical approach.

LEPRb is highly expressed in different hypothalamic nuclei and other CNS regions involved in the control of energy balance (Elmquist et al. 1998). In the ARC, the POMC, and AgRP neurons are the direct targets of leptin (Cheung et al. 1997, Elias et al. 1999, Cowley et al. 2001). The ablation of LEPRb in POMC neurons, AgRP neurons, or both populations of neurons causes increased body weight, emphasizing the importance of leptin signaling (Table 1). However, the magnitude of these changes is smaller than that observed in mice globally lacking Lepr, indicating the existence of additional subsets of neurons mediating the effects of leptin on food intake and body weight. Leptin binds to LEPRb and activates JAK2, which, in turn, phosphorylates several tyrosine residues on the intracellular domain of the LEPRb. This results in the activation, dimerization, and nuclear translocation of STAT3 (Robertson et al. 2008). In the nucleus, STAT3 enhances Pomc gene expression and inhibits Agrp gene expression (Munzberg et al. 2003, Kitamura et al. 2006). Accordingly, Stat3 deficiency in POMC neurons results in overweight and Pomc gene transcriptional defects in females (Table 1). This signaling cascade is negatively regulated by the suppressor of cytokine signaling 3 (SOCS3), the expression of which is also regulated by STAT3 and protein tyrosine phosphatase 1B (PTP1B) (Robertson et al. 2008). Consistent with this, deletion of either Socs3 or Ptp1b (Ptpn1) in POMC neurons leads to reduced adiposity, improved leptin sensitivity, and increased energy expenditure under HFD conditions (Table 1). In addition, leptin also activates the phosphatidylinositol-3-kinase (PI3K) pathway. A variety of genetic mouse models targeting the catalytic or regulatory subunits of PI3K in specific subsets of neurons have been reported with divergent results (Table 1). Overall, these studies indicate that PI3K is required for leptin-mediated regulation of energy balance and that, contrary to the prevailing view, the catalytic p110 $\beta$ subunit in ARC neurons may play a more prominent role than p110 $\alpha$. PI3K generates phosphatidylinositol-3,4,5-triphosphate $\left(\mathrm{PIP}_{3}\right)$ and activates downstream targets such as phosphoinositide-dependent kinase 1 (PDK1) and AKT (also known as protein kinase B), which consecutively phosphorylates the transcription factor forkhead box protein O1 (FOXO1). Upon phosphorylation, FOXO1 is excluded from the nucleus, allowing STAT3 to bind to Pomc and Agrp promoters, thereby stimulating and inhibiting respectively the expression of these neuropeptides (Kitamura et al. 2006). These findings are consistent with the effects of genetic manipulations in vivo (Table 1). PI3K signaling is counterbalanced by phosphatase and tensin homolog (PTEN), which specifically dephosphorylates $\mathrm{PIP}_{3}$. The loss of Pten in POMC neurons results in increased $\mathrm{PIP}_{3}$ signaling and dietsensitive obesity via $\mathrm{K}_{\mathrm{ATP}}$ channel modulation, suggesting a role for the PI3K pathway in the regulation of the activity of this channel (Table 1). Overall, leptin stimulates Pomc transcription, depolarizes POMC neurons, and also increases $\alpha$-MSH processing and secretion (Cowley et al. 2001, Munzberg et al. 2003, Guo et al. 2004) while attenuating the expression and release of orexigenic NPY and AGRP neuropeptides (Stephens et al. 1995, Mizuno \& Mobbs 1999).

Insulin, produced by pancreatic $\beta$-cells, has traditionally been associated with glucose metabolism, but compelling evidence indicates that insulin also acts as an anorectic signal within the CNS. Glucose-induced insulin is secreted into the bloodstream in proportion to fat stores (Bagdade et al. 1967) and enters the brain through a saturable transport mechanism (Baura et al. 1993). The i.c.v. or intrahypothalamic administration of insulin to primates and rodents reduces food intake (Woods et al. 1979, McGowan et al. 1993, Air et al. 2002). Insulin receptor (IR (INSR)), as well as its downstream signaling machinery, is expressed in hypothalamic areas involved in the control of appetite (Havrankova et al. 1978, Corp et al. 1986) and colocalizes with AgRP and POMC neurons (Benoit et al. 2002). Surprisingly, the loss of Insr in either POMC or AgRP neurons does not lead to alterations in energy balance (Table 1), although hepatic glucose production defects have been observed in mice lacking $I r$ in AgRP neurons (Konner et al. 2007). Neuron-specific IR reconstitution in $\mathrm{L} 1$ mice (which have $>90 \%$ reduction of IR levels in the ARC) confirmed that insulin signaling in $\mathrm{AgRP}$ and POMC neurons controls glucose metabolism and energy expenditure respectively (Table 1 ). Insulin binding to IR leads to the autophosphorylation of the receptor and the consequent recruitment of IRS proteins, which converge with the leptin pathway at the PI3K level (Xu et al. 2005b). Negative regulators of the LEPR, such as SOCS3 and PTP1B, also directly inhibit the IR and its signaling cascade acting on IRS1. The activation of the

Published by Bioscientifica Ltd 


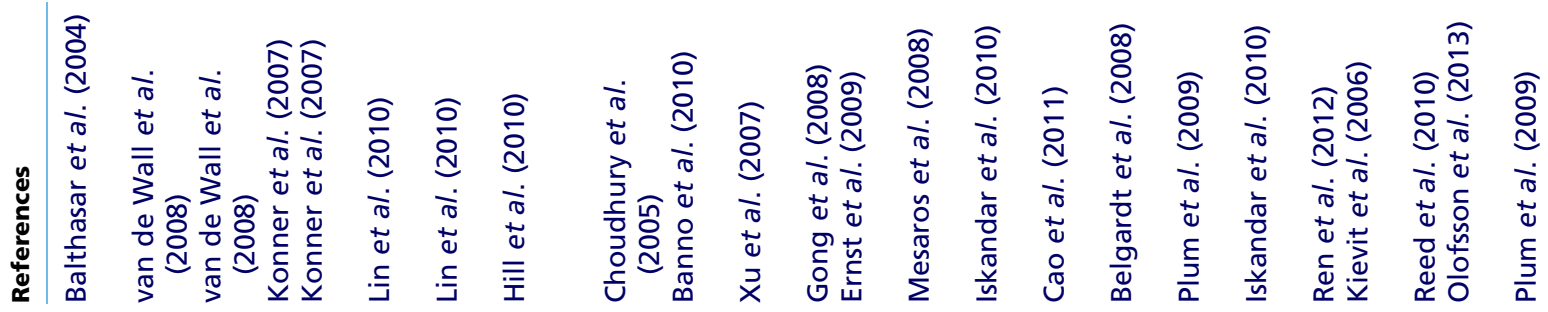
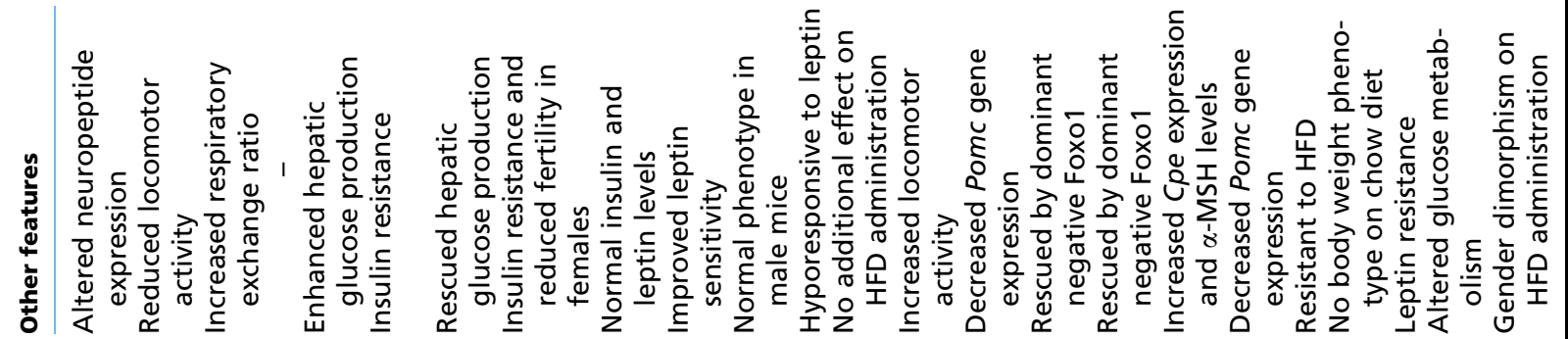

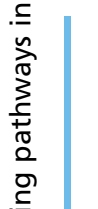

논본

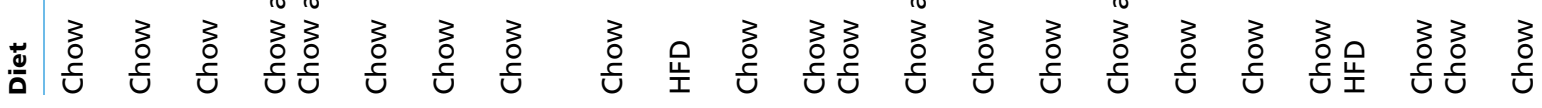

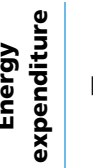

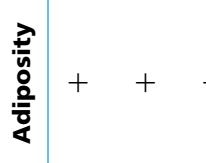

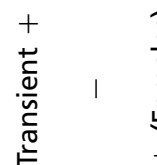
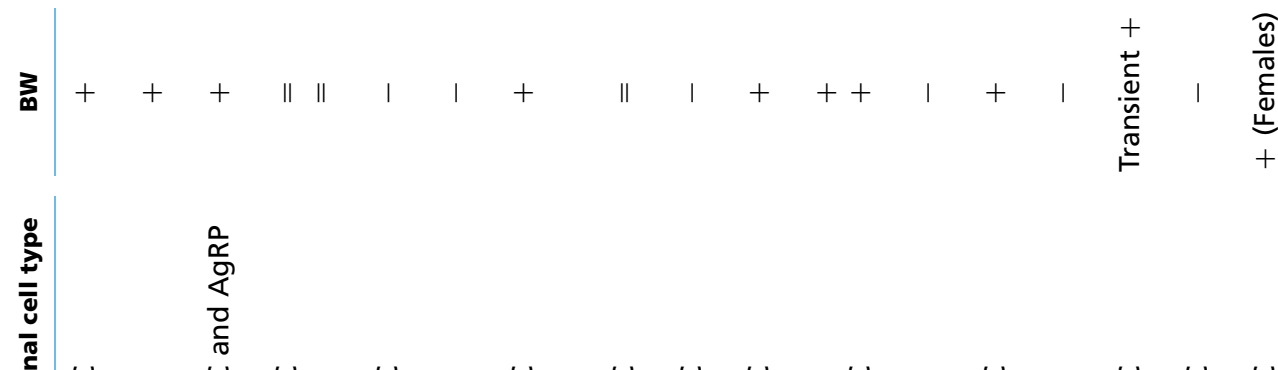

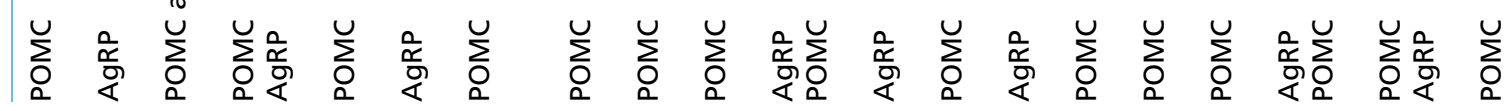

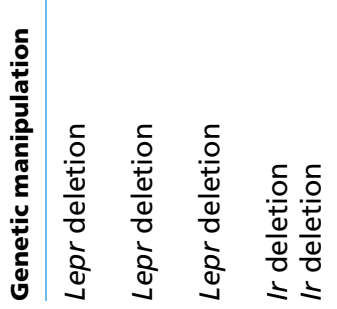

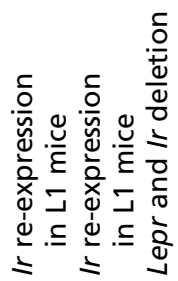

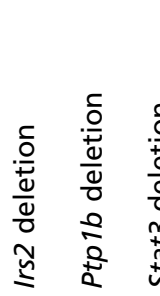

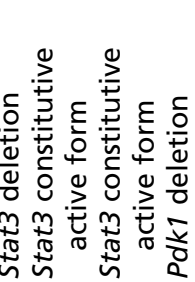

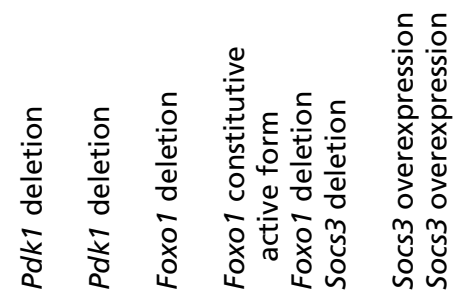

$\frac{\partial}{\bar{u}} \frac{.}{\tilde{u}}$

항

$\frac{0}{0}$
$\frac{0}{0}$
$\frac{0}{0}$
$\frac{0}{d}$
$\frac{0}{0}$


IR signaling pathway results in reduced expression of NPY and increased levels of POMC in the ARC, thus stimulating an anorexigenic effect (Schwartz et al. 1992, Sipols et al. 1995, Benoit et al. 2002).

Leptin and insulin also regulate the activity of AMPK, an evolutionarily conserved cellular and organismal energy sensor that plays a central role in the hypothalamic regulation of energy homeostasis (Minokoshi et al. 2004, Claret et al. 2007). In particular, both hormones inhibit AMPK and its downstream targets in the hypothalamus (Minokoshi et al. 2004). A recent study has reported that leptin-mediated inhibition of AMPK is achieved through phosphorylation on serine ${ }^{491}$ by mTOR/p70S6K, an event that is necessary for the action of leptin on food intake and body weight (Dagon et al. 2012).

The molecular significance and detailed mechanisms of the different components of the aforementioned signaling pathways have become better understood, thanks to the advent of the Cre/Lox technology. Table 1 summarizes the phenotypes of several conditional mouse models that provided valuable information in this regard.

\section{GI hormones}

Ghrelin is a 28-amino acid acylated hormone, mainly produced by the stomach, which exerts its biological actions on energy balance through the growth hormone secretagogue receptor (GHSR; Kojima et al. 1999, Sun et al. 2004). Circulating ghrelin levels are increased under fasting conditions and reduced after refeeding (Tschop et al. 2000). The central and peripheral administration of ghrelin in rodents has been shown to robustly promote feed intake, adiposity, and body weight gain (Tschop et al. 2000, Nakazato et al. 2001). Likewise, ghrelin also enhances appetite in humans (Wren et al. 2001). GHSR is expressed in AgRP neurons of the ARC (Willesen et al. 1999), and this population of neurons is essential for the mediation of the orexigenic effects of ghrelin (Chen et al. 2004). Ghrelin is able to stimulate the transcription of $N p y$ and Agrp, and it also increases the number of stimulatory synapses on AgRP neurons while increasing the number of inhibitory synapses on POMC neurons (Kamegai et al. 2001, Nakazato et al. 2001, Cowley et al. 2003). However, neuronal activation and positive energy balance have also been reported after ghrelin administration in the PVN, LHA, and hindbrain and in the mesolimbic reward pathway (Faulconbridge et al. 2003, Naleid et al. 2005).

Peptide tyrosine tyrosine (PYY) is mainly released from the L-cells of the intestinal epithelium in response to nutrient ingestion (Tatemoto \& Mutt 1980, 
Adrian et al. 1985). Circulating PYY levels are proportional to calorie intake and are reduced under fasting conditions (Adrian et al. 1985). Two endogenous forms, $\mathrm{PYY}_{1-36}$ and $\mathrm{PYY}_{3-36}$, are synthesized and secreted. The latter form is the most abundant in the bloodstream and exerts a direct action in the ARC. This has been demonstrated by peripheral and intra-ARC administration of $\mathrm{PYY}_{3-36}$, which increases neuronal activity in this region and reduces appetite and body weight in a dose-dependent manner (Batterham et al. 2002, Challis et al. 2003). These anorexigenic effects are mediated via the inhibition of ARC Y2 receptors, as demonstrated by pharmacological (Abbott et al. 2005, Scott et al. 2005) and genetic (Batterham et al. 2002) studies, which eventually leads to increased $\alpha$-MSH and reduced NPY release (Batterham et al. 2002). The effects of $\mathrm{PYY}_{3-36}$ in the brainstem and the vagal-brainstem circuit have also been confirmed, as the peripheral delivery of this peptide has been shown to increase neuronal activity in NTS and AP neurons and stimulate vagal afferent firing (Koda et al. 2005, Blevins et al. 2008). Consistent with a role for PYY in the regulation of appetite and body weight, transgenic mice globally lacking or overexpressing Pyy exhibit opposite alterations in energy balance control (Batterham et al. 2006, Boey et al. 2008).

GLP1, the cleavage product of proglucagon in the intestine and brain, is mainly secreted from intestinal L-cells. Similar to PYY, circulating GLP1 levels are high following a meal and are low under fasting conditions. This hormone exerts a strong incretin effect, via the GLP1 receptor (GLP1R) expressed in pancreatic islets, enhancing insulin secretion after carbohydrate ingestion (Kreymann et al. 1987). GLP1R is also expressed in key CNS areas involved in the control of energy balance, such as the hypothalamus and brainstem (Merchenthaler et al. 1999). A number of studies have shown that the central or sitespecific administration of GLP1 or GLP1 analogs inhibits food intake in rodents (Tang-Christensen et al. 1996, Turton et al. 1996, McMahon \& Wellman 1998, Hayes et al. 2008). Interestingly, neurons expressing the proglucagon gene are present in the NTS, suggesting the existence of a local circuit involved in the control of appetite (Merchenthaler et al. 1999). In fact, recent studies have provided evidence for a dual (peripheral and central) role of GLP1 in the suppression of appetite mediated by local vagal afferents and a gut-brain feedback mechanism (Barrera et al. 2011).

CCK is postprandially secreted from I-cells from the small intestine and its systemic delivery suppresses food intake in both animal models and humans
(Gibbs et al. 1973, Gibbs \& Smith 1977, Kissileff et al. 1981). CCK1 and CCK2 receptors are expressed in the brainstem and hypothalamus, but the anorectic effects of CCK are critically mediated by vagal sensory neurons that project into the NTS (Moran et al. 1997). Interestingly, NTS POMC neurons are activated by CCK and brainstem MC4R signaling is required for CCK-induced suppression of appetite (Fan et al. 2004). It has also been reported that ghrelin attenuates and leptin synergistically potentiates the effects of CCK on appetite (Barrachina et al. 1997, Lee et al. 2011).

\section{Neural circuits regulating homeostatic energy balance}

Certain physiological conditions, such as the prandial state, are associated with notable changes in the circulating concentration of metabolites and hormones involved in the regulation of whole-body energy homeostasis. For example, in a postabsorptive situation, circulating cues of energetic surfeit (leptin, insulin, GLP1, PYY, and glucose) are elevated, while cues of energetic deficit (ghrelin) are reduced. The opposite is true under fasting conditions. These hormones act in concert to engage specific neuronal circuits in different brain regions, including the hypothalamus and brainstem, establishing reciprocal and dynamic interactions to restore systemic energy balance. In this section, we summarize the main circuits and the neuronal responses engaged by leptin and ghrelin, as prototypical examples of anorexigenic and orexigenic signals respectively.

\section{ARC neuronal circuits: POMC, AgRP, and RIPCre neurons}

Melanocortin peptides and NPY are two basic components of a critical hypothalamic circuit involved in the convergence and integration of nutritional and hormonal cues aimed at regulating organismal energy balance. In the $\mathrm{ARC}$, the POMC, and AgRP neurons are located in proximity to each other and project in parallel into similar brain areas expressing MCRs. Both POMC and AgRP neurons are able to sense a number of peripheral (leptin, insulin, and ghrelin) and central (NPY, GABA, serotonin, and melanocortin) signals, which are able to acutely modulate their electrical activity influencing the release of neuropeptides and neurotransmitters to ultimately regulate appetite, energy expenditure, and metabolism.

In general terms, POMC (anorexigenic) and AgRP (orexigenic) neurons have opposite physiological functions, which are largely the consequence of the

Published by Bioscientifica Ltd 
contrasting actions of $\alpha$-MSH and AGRP peptides on MCRs: while $\alpha$-MSH is an endogenous MCR agonist, AGRP is an inverse agonist (Haskell-Luevano \& Monck 2001, Nijenhuis et al. 2001, Tolle \& Low 2008). Indeed, substantial experimental evidence indicates that the agonism of MCRs attenuates appetite and enhances energy expenditure, whereas their antagonism has essentially the opposite effects (Fan et al. 1997, Harrold et al. 1999, Hwa et al. 2001). This is consistent with data showing that the loss of or mutations in MC3R and $M C 4 R$ genes cause obesity both in rodents and in humans (Huszar et al. 1997, Butler et al. 2000, Farooqi 2008). In addition to the inhibition of MCR signaling, the orexigenic actions of AgRP neurons are also mediated by the release of NPY and GABA.

The anorexigenic effects of leptin are basically achieved by repressing AgRP neurons and activating POMC neurons (Fig. 1A). Leptin enhances Pomc gene expression and processing into $\alpha$-MSH (Schwartz et al. 1997, Thornton et al. 1997, Mizuno et al. 1998). Electrophysiological studies have demonstrated that locally applied leptin is able to depolarize (excite) POMC neurons (Cowley et al. 2001, Claret et al. 2007, 2011, Hill et al. 2008, Al-Qassab et al. 2009, Qiu et al. 2010) probably through TRPC channels (Qiu et al. 2010). In contrast, leptin inhibits the transcription of Npy and Agrp genes in the hypothalamus (Stephens et al. 1995, Schwartz et al. 1996, Mizuno \& Mobbs 1999). Electrophysiological recordings have shown that leptin decreases the GABAergic-mediated tone induced by AgRP neurons onto neighboring POMC neurons, resulting in the disinhibition of POMC neuron activity (Cowley et al. 2001). The ability of leptin to directly hyperpolarize (inhibit) AgRP neurons is controversial (Cowley et al. 2001, Claret et al. 2007, Al-Qassab et al. 2009), but studies in rats have reported leptin-mediated inhibition of identified NPY neurons (van den Top et al. 2004). In addition, leptin also acts directly on presynaptic GABAergic neurons that do not express AGRP, reducing the inhibitory input to postsynaptic POMC neurons, thus further contributing to the maintenance of the anorexigenic actions mediated by this hormone (Fig. 1A; Vong et al. 2011).

On the other hand, under conditions of negative energy balance, circulating ghrelin levels are increased. The actions of ghrelin on food intake and energy balance are mediated by AgRP neurons, as mice lacking Agrp and Npy are insensitive to the orexigenic effects of external ghrelin (Chen et al. 2004, Luquet et al. 2007). In line with this, ghrelin increases the expression of Npy and Agrp transcripts (Kamegai et al. 2001, Nakazato et al. 2001) and depolarizes AgRP neurons while increasing the number of GABAergic inhibitory synapses on POMC neurons (Fig. 1B) (Cowley et al. 2003, van den Pol et al. 2009, Yang et al. 2011, Atasoy et al. 2012). The importance of these GABAergic stimuli in the control of energy balance has been substantially demonstrated (Horvath et al. 1997, Wu et al. 2009, 2012, Wu \& Palmiter 2011), and conditional deletion of the vesicular GABA transporter in AgRP neurons blunts the inhibitory tone onto postsynaptic POMC neurons, leading to an enhanced melanocortigenic output and a lean phenotype (Tong et al. 2008). Moreover, AGRP and NPY directly hyperpolarize POMC neurons and decrease the production and release of $\alpha-\mathrm{MSH}$, further inhibiting the activity of this population of neurons (Roseberry et al. 2004, Smith et al. 2007, Cyr et al. 2013). Thus, AgRP neurons are able to negatively modulate the anorexigenic effects of POMC neurons by direct (GABAergic synapsis) and indirect (MCR antagonism) mechanisms (Fig. 1B).

In addition to changes in neuropeptide release, leptin and ghrelin also exert rapid and reversible effects on synaptic connections onto POMC and AgRP neurons. Seminal studies carried out at the Horvath laboratory have provided the first evidence for synaptic plasticity in hypothalamic energy balance circuits and established the basis for a new mechanism by which these hormones dynamically regulate circuit responsiveness to control energy homeostasis (Pinto et al. 2004). The role of synaptic remodeling in neuronal circuits regulating metabolism has recently been reviewed in detail (Zeltser et al. 2012, Dietrich \& Horvath 2013).

A novel subpopulation of ARC neurons involved in the control of energy balance (defined by virtue of Cre-mediated expression of rat insulin II promoter-Cre transgene and called RIPCre neurons) has recently been described. Comparative electrophysiological and histological studies indicate that RIPCre neurons constitute a distinct population from POMC or AgRP neurons (Choudhury et al. 2005). However, close apposition of these neuronal subsets suggests that RIPCre neurons may be the targets of POMC and/or AgRP neurons. Indeed, bath application of a melanocortin agonist has been found to cause direct long-lasting depolarization and increased firing in ARC RIPCre neurons (Choudhury et al. 2005). Interestingly, insulin has also been found to depolarize these neurons, while leptin has been found to not cause any electrophysiological effect (Choudhury et al. 2005).

Although a number of mouse genetic studies indicate that ARC RIPCre neurons regulate systemic energy balance (Cui et al. 2004, Choudhury et al. 2005), this interpretation

Published by Bioscientifica Ltd 
A

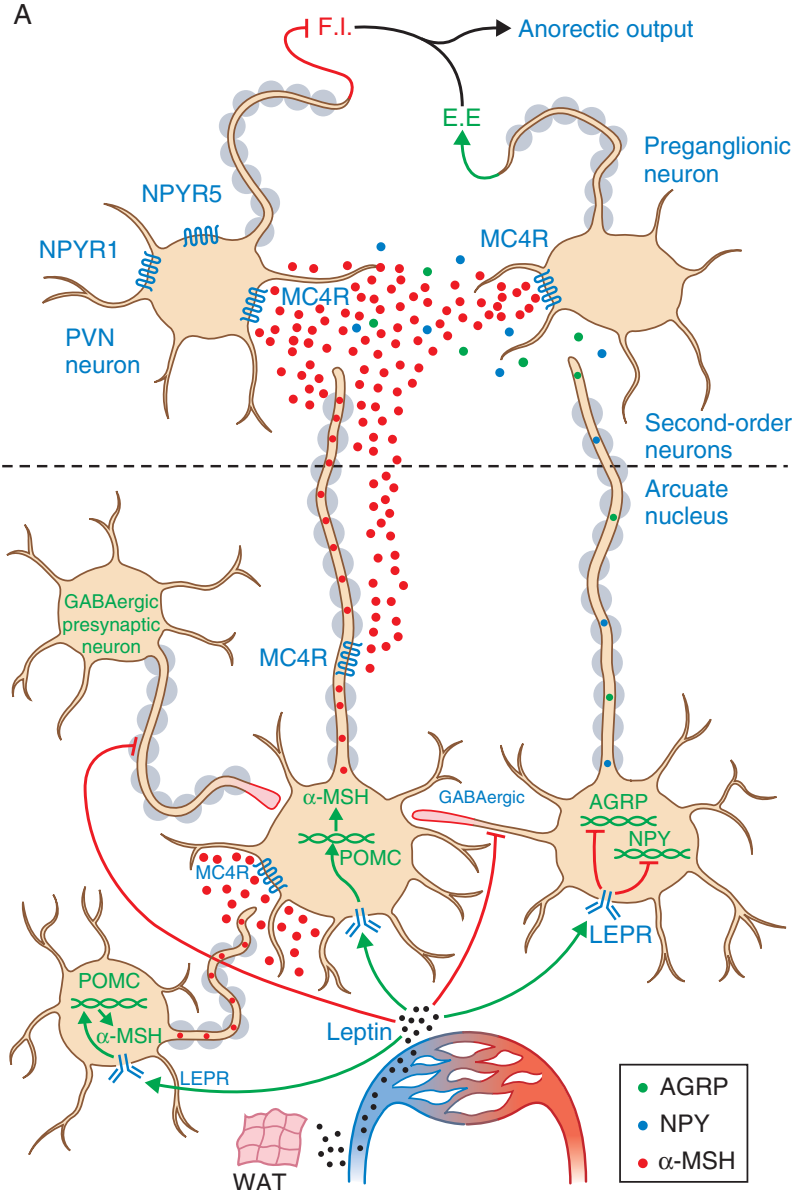

B

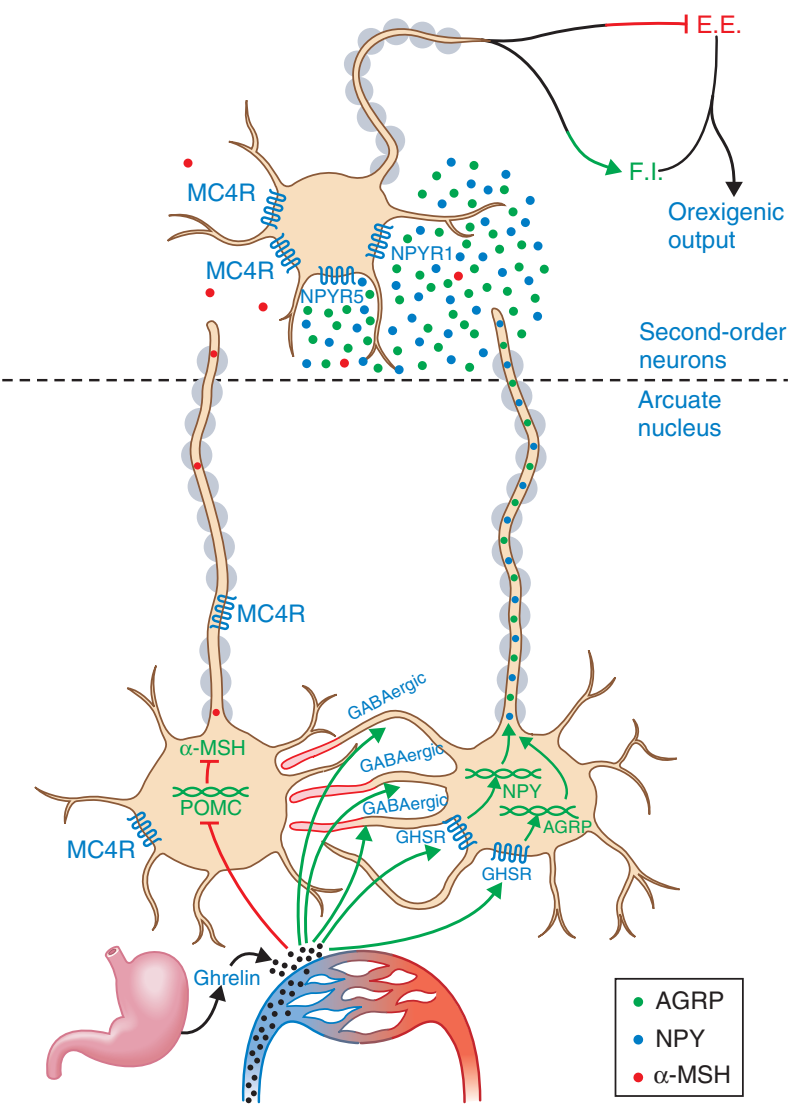

in reduced food intake and increased energy expenditure. (B) Ghrelin exerts its orexigenic effects through AgRP neurons. Ghrelin increases inhibitory GABAergic projections onto POMC neurons and enhances the expression and release of NPY and AGRP. In the PVN, AGRP acts as a MC4R inverse agonist, while NPY binds to $Y 1$ and $Y 5$ receptors. Collectively, these events lead to increased orexigenic output. Red arrows and synapses, inhibitory effect and green arrows, activation effect. WAT, white adipose tissue.

neurons are complex, as suggested by heterogeneous electrophysiological recordings demonstrating subsets of neurons being depolarized, hyperpolarized, or silent (Choudhury et al. 2005, Kong et al. 2012). Nevertheless, the ability of leptin to increase energy expenditure is impaired in mice lacking vesicular GABA transporter in RIPCre neurons, indicating a functional effect of this hormone on these neurons (Kong et al. 2012).

Taken together, current evidence indicates that a local ARC circuit constituted by the 'first-order' POMC, AgRP, and RIPCre neurons plays a key role in the integration of humoral signals reporting on energy conditions. This is achieved by a sophisticated and multilevel http://joe.endocrinology-journals.org DOI: 10.1530/JOE-13-0398
๑ 2014 Society for Endocrinology Printed in Great Britain 
organizational structure that allows the accurate regulation of orexigenic and anorexigenic outputs through direct and indirect mechanisms.

\section{Downstream neurocircuitry engaged by hypothalamic neuron activity}

Given that POMC and AgRP neurons are the sole source of MCR ligands in the brain, a fine balance between $\alpha$-MSH and AGRP is necessary to precisely regulate their mediated physiological outputs on MC4Rs in target areas. These receptors are localized in many nuclei involved in the regulation of energy balance where POMC and AgRP neurons send axon projections. MC4Rs are G-proteincoupled receptors that stimulate adenylyl cyclase, thereby increasing intracellular cAMP levels (Florijn et al. 1993). A series of elegant studies using a cell-specific MC4R re-expression strategy indicate that MC4Rs in the PVN are mainly involved in the control of food intake (Balthasar et al. 2005), while MC4Rs in autonomic preganglionic neurons regulate energy expenditure and hepatic glucose production (Rossi et al. 2011) (Fig. 1A). Furthermore, and contrary to the prevailing view, a recent report has shown that POMC neurons also express MC4Rs that contribute to the regulation of body weight and composition through changes in both feeding behavior and energy expenditure (do Carmo et al. 2013). This autoregulatory mechanism, induced by $\alpha$-MSH released from the same cell and/or neighboring POMC neurons, could represent an additional layer of regulation within a widely segregated network of melanocortin receptors involved in the regulation of homeostatic (appetite) and autonomic (thermogenesis, hepatic metabolism, and insulin release) functions (Fig. 1A).

NPY receptors are Gi/o-protein-coupled receptors that reduce cAMP production, leading to the activation of G-protein-gated inwardly rectifying $\mathrm{K}^{+}$(GIRK) channels and inhibition of voltage-dependent $\mathrm{Ca}^{2+}$ channels (Sohn et al. 2013). The precise roles of NPY receptors and their contribution to the mediation of the orexigenic effects of NPY have been difficult to delineate due to the paradoxical phenotypes of receptor KO mouse models. This is probably the consequence of receptor redundancies and compensatory mechanisms exhibited after the application of germline deletion strategies. Despite these limitations, pharmacological and genetic studies indicate that the orexigenic actions of NPY are mediated by postsynaptic Y1 and Y5 within the PVN (Nguyen et al. 2012, Sohn et al. 2013; Fig. 1B). Notably NPY from ARC neurons acts through PVN Y1, resulting in a functional inhibition of TH tonus and BAT thermogenesis (Shi et al. 2013).
Furthermore, NPY may also decrease pro-TRH transcription and proconvertase 2-mediated pro-TRH processing in the PVN through Y1/Y5 receptors (Cyr et al. 2013). Taken together, abundant amounts of evidence suggest that the effects of ARC NPY on energy balance are principally mediated by the PVN. However, it is important to note that other sources of NPY may also play a role in the regulation of energy balance.

\section{Correlating neuronal circuit activity with behavioral responses by pharmacogenetic and optogenetic techniques}

Most of the experimental findings that have allowed researchers to outline the models suggested so far are largely the result of circumstantial evidence. However, the recent development of pharmacogenetic and optogenetic techniques has provided a way to exert temporally and spatially precise control over the activity of defined circuit elements. This permits the establishment of causal connections between circuit activity and behavioral responses (Sternson 2013).

Using an elegant combination of optogenetics and mouse genetic approaches, Aponte et al. (2011) have confirmed that the selective activation of AgRP neurons is sufficient to evoke voracious feeding behavior in mice, without previous training and independent of melanocortin signaling. The level of neuronal activation has been found to correlate with the magnitude, dynamics, and duration of the induced behavioral response. Furthermore, continuous photostimulation is required to maintain evoked feeding behaviour, indicating that the activation of AgRP neurons does not initiate a sustained propagating effect (Aponte et al. 2011). In contrast, prolonged (but not brief) optogenetic stimulation of POMC neurons has been shown to result in reduced food intake and body weight gain, which requires downstream MC4R activity (Aponte et al. 2011).

The behavioral effects on food intake caused by AgRP or POMC neuron activation have been further supported by studies using pharmacogenetic (designer receptors exclusively activated by designer drugs (DREADDs)) technology. Pharmacogenetic activation of AgRP neurons rapidly induces feeding and food-seeking behaviors associated with decreased energy expenditure and enhanced adiposity (Krashes et al. 2011). Consistent with the optogenetic data (Aponte et al. 2011), long-term stimulation of ARC POMC neurons is necessary to reduce appetite. Interestingly, the acute stimulation of NTS POMC neurons has been shown to generate an immediate suppression of food intake (Zhan et al. 2013).

Published by Bioscientifica Ltd 
In a subsequent study, the Sternson group performed a series of experiments to determine which brain regions and cell types mediate evoked feeding behavior triggered by activated AgRP neurons. The authors used optogenetic approaches to map synaptic connections downstream of AgRP neurons and assessed their role in terms of ingestive behavior by perturbing electrical activity in presynaptic and postsynaptic neuronal types (Atasoy et al. 2012). Notably the authors found that ARC AgRP neurons induce evoked feeding behavior through inhibitory input onto oxytocin neurons in the PVN, while ARC POMC neurons are involved in the long-term control of appetite and energy balance (Atasoy et al. 2012).

Collectively, these results emphasize the previously unrecognized importance of the temporal and spatial activation of POMC and AgRP neurons. Thus, ARC AgRP and NTS POMC neurons could be involved in the regulation of acute feeding behavior while ARC POMC neurons may be involved in long-term responses. This demonstrates the existence of multiple, distinct behavioral and anatomical modules that act in synchrony to regulate whole-body energy balance. The use of these tools in the field of central control of energy balance has provided novel valuable information and has confirmed previous findings. However, it has also generated some controversial observations. Further research needs to be conducted to precisely define the importance of these factors and to reconcile these observations with previous evidence (Mercer et al. 2013). Nevertheless, these reports demonstrate that optogenetics and pharmacogenetics are exceptionally useful tools to study the interrelationships between synaptology, neuronal circuit activity, and behavioral outputs.

\section{New players in energy balance control}

\section{Non-neuronal cell types: macroglia and microglia}

Glial cells have traditionally been considered satellite neuronal partners with supportive and structural roles. However, in recent years, glial cells have acquired a new rank and are now regarded as active players in many physiological functions including energy balance control.

Astrocytes are star-shaped cells that are involved in a number of functions, such as metabolic support to neurons and transmitter uptake and release as well as synaptic remodeling (Sofroniew \& Vinters 2010). Astrocytes express LEPR (Cheunsuang \& Morris 2005, Hsuchou et al. 2009b), and modifications in circulating leptin levels alter hypothalamic astrocyte expression of structural proteins as well as glutamate and glucose transporters (Garcia-Caceres et al. 2011, Fuente-Martin et al. 2012). This may cause changes in the synaptic plasticity and excitability of surrounding neurons, leading to metabolic adaptations. In fact, HFD administration in rodents is associated with increased glial coverage of POMC neuron perikarya (Horvath et al. 2010). It has also been reported that DIO mice exhibit increased expression of functional astrocytic LEPR in the hypothalamic region, an effect that may play a role in the development of leptin resistance (Hsuchou et al. 2009a). Indeed, loss of astrocytic Lepr under HFD conditions provides partial protection against developing disturbances in neuronal leptin signaling (Jayaram et al. 2013).

Obesity and lipid overload induce chronic low-grade inflammation in the hypothalamus (Thaler et al. 2010). This is regarded as a protective effect, which is mainly promoted by microglial cells that have immunitary actions in the CNS. HFD feeding selectively and rapidly activates microglia in the hypothalamus and increases the production of proinflammatory cytokines (De Souza et al. 2005, Milanski et al. 2009, Thaler et al. 2012). Interestingly, it has been demonstrated that moderate physical activity reduces hypothalamic microglial activation independently of body mass (Yi et al. 2012). Enhanced hypothalamic microglial activation has also been reported in rodents and primates after nutritional manipulations during the prenatal or perinatal period (Grayson et al. 2010, Tapia-Gonzalez et al. 2011).

Tanycytes have recently emerged as novel modulators of the hypothalamic networks that control energy balance. They contact the cerebrospinal fluid and send processes that come into proximity with neurons into the ARC and VMN (Bolborea \& Dale 2013). Although it is not known whether tanycytes are able to modulate the activity of hypothalamic neurons, several lines of evidence suggest that this particular cell type may be involved in the regulation of energy homeostasis. For example, tanycytes respond to fluctuations in glucose concentration (Frayling et al. 2011), express a number of genes related to energy homeostasis control (Bolborea \& Dale 2013), and regulate the permeability properties of the fenestrated capillaries of the ME, which may constitute a way of modulating the access of metabolites into the ARC (Langlet et al. 2013). Intriguingly, tanycytes may be a novel population of adult neural stem cells in the hypothalamus. Tanycytes express stem cell markers, including nestin and SOX2 (Lee et al. 2012), and lineage-tracing studies have shown that they give rise to neurons in vivo with functional implications. While short-term HFD feeding promotes hypothalamic neurogenesis in pre-adult ages (Lee et al. 2012), chronic

Published by Bioscientifica Ltd 
HFD administration causes depletion of hypothalamic neural stem cells (Li et al. 2012). Furthermore, the manipulation of hypothalamic neurogenesis in adult mice has also produced divergent results. Selective inhibition of ME neurogenesis in adult mice fed a HFD resulted in reduced weight gain and adiposity due to enhanced energy expenditure (Lee et al. 2012). By contrast, genetic IKK $\beta / \mathrm{NF}-\kappa \mathrm{B}$ activation in SOX2-positive hypothalamic cells led to overeating and weight gain (Li et al. 2012). It is important to note that these strategies did not exclusively target tanycytes and so these metabolic effects cannot be solely attributed to this cell type. Together, these results indicate that neurogenesis after short- or long-term HFD administration may have a compensatory or detrimental effect respectively on cell fate. These differences can also be the consequence of targeting distinct tanycyte populations (Bolborea \& Dale 2013).

\section{Epigenetic mechanisms}

The interplay between genetic and environmental factors (nutrition, maternal health, chemicals, lifestyle, etc.) during the prenatal or perinatal period and their influence on the development of energy balance and metabolic alterations into adulthood have recently received substantial interest. In both humans and animal models, prenatal or perinatal nutritional manipulations lead to chronic metabolic disturbances in terms of feeding behavior, energy expenditure, leptin sensitivity, and glucose homeostasis. These metabolic defects may be partially the consequence of abnormal development of appetite-regulating neuronal circuits due to perinatal programming (Contreras et al. 2013). Epigenetic changes have been proposed as likely candidates to mediate, at least in part, these neuronal programming events, but a limited number of studies have explored this hypothesis. The epigenetic machinery that controls chromatin dynamics includes DNA methylation, posttranslational histone modifications, and non-coding RNAs. Neonatal overfeeding in rats, which results in overweight and metabolic syndrome, is associated with the hypermethylation of the Pomc gene promoter (Plagemann et al. 2009). The extent of this DNA methylation is negatively correlated with the expression of POMC in relation to leptin and insulin levels, indicating the functionality of acquired epigenomic alterations (Plagemann et al. 2009). In the same overnutrition model, Plagemann et al. (2010) also found increased methylation of the Insr promoter in the hypothalamus. Similarly, epigenetic remodeling of hypothalamic genes induced by mild maternal undernutrition
(Stevens et al. 2010, Begum et al. 2012) or stress (Paternain et al. 2012) has also been reported to be associated with altered energy balance and metabolism in experimental animal models. In humans, different methylation patterns of $P O M C$ and NPY promoter regions in leukocytes have been proposed as biomarkers to predict weight regain after an energy restriction program (Crujeiras et al. 2013). Collectively, this evidence supports the hypothesis that early prenatal or postnatal environmental perturbations cause chronic metabolic alterations that are partially the consequence of epigenetic changes in key genes and areas of the CNS involved in the control of energy balance. Nevertheless, further research is warranted to address the significance of these epigenetic events.

MicroRNAs (miRNAs), a class of small, non-coding RNAs that regulate gene expression at the posttranscriptional level, have recently been suggested to be involved in the hypothalamic control of energy balance. It has been demonstrated that the expression of Dicer1, an essential endoribonuclease for miRNA maturation, is regulated by nutrient availability and excess in the hypothalamus (Schneeberger et al. 2013). Furthermore, we have also shown that deletion of Dicer1 in POMC neurons leads to an obese phenotype characterized by increased adiposity, hyperleptinemia, defective glucose metabolism, and alterations in the pituitary-adrenal axis. This phenotype is associated with a progressive POMC neuron degeneration, indicating a key role for miRNAs in the survival of this population of neurons (Greenman et al. 2013, Schneeberger et al. 2013). High-throughput sequencing studies in ARC and PVN of rats have shown a specific miRNA enrichment pattern that could be used to define a prototypic profile in these brain regions. These miRNAs include seven of the eight genes of the let-7 family, the two miR-7 genes, miR-9 gene, and 5 ' copy of the three miR-30 loci (Amar et al. 2012). Moreover, in situ hybridization experiments have revealed a limited and distinct expression of miR-7a in the hypothalamus, preferentially colocalizing with AgRP neurons (Herzer et al. 2012). Despite these efforts in describing the miRNA transcriptome and patterns of expression in the hypothalamus, the role of specific miRNAs in particular neuronal circuits in the regulation of whole-body energy balance still remains unknown.

\section{Concluding remarks: neuronal circuitry integration and physiological responses}

As has been outlined above, organismal energy balance is regulated by many factors through complex and

Published by Bioscientifica Ltd 


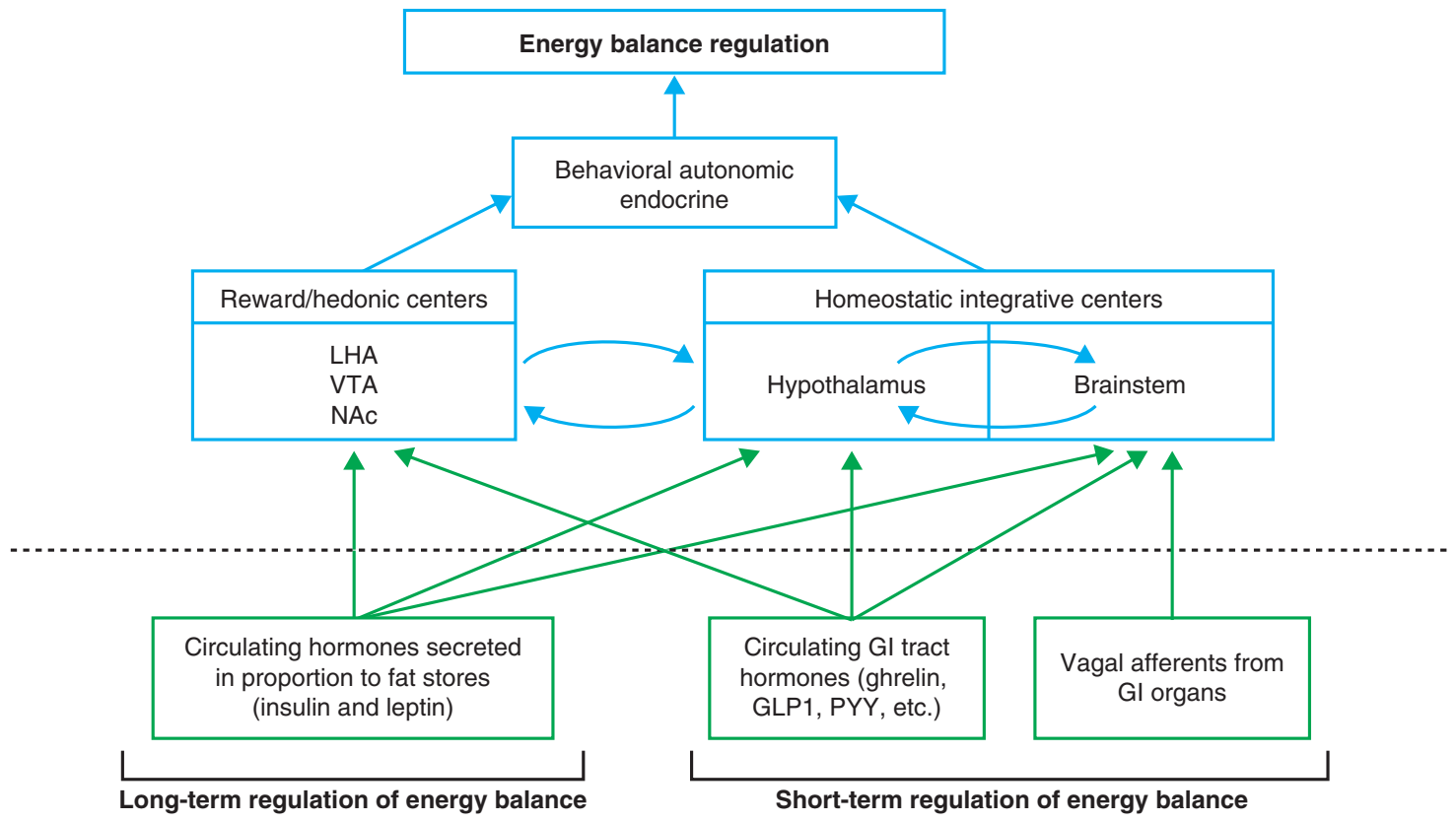

\section{Figure 2}

Schematic integration of the different levels of food intake and energy balance regulation. Food intake and energy balance are coordinately regulated by homeostatic and non-homeostatic neural mechanisms. Circulating hormones and vagus stimuli inform the CNS about whole-body nutritional and energy status. Leptin and insulin are believed to be involved in the long-term regulation of energy balance, while GI hormones and vagal afferents represent a short-term regulatory mechanism. These hormones act in concert to engage specific neuronal circuits in homeostatic and hedonic centers, establishing dynamic and complex interactions between these different brain regions to elaborate coordinated endocrine, autonomic, and behavioral responses to regulate energy balance. Sensory, emotional, and social cues also influence ingestive behaviors probably through non-homeostatic and higher brain structures. LHA, lateral hypothalamic area; VTA, ventral tegmental area; NAc, nucleus accumbens. multi-level integration processes that involve multiple neuronal circuits. The homeostatic system is basically influenced by long-term (leptin and insulin) and short-term (GI hormones and vagal inputs) signals that act in concert to engage specific neuronal circuits in the hypothalamus and brainstem aimed at fulfilling whole-body metabolic needs. In addition to this homeostatic module, the corticolimbic and mesolimbic centers (which include the ventral tegmental area, nucleus accumbens, prefrontal cortex, hippocampus, and amygdala) integrate cognitive, hedonic, and emotional stimuli in a non-homeostatic process (Berthoud 2011). Circulating energy balance signals, such as leptin and ghrelin, also target hedonic networks to modulate appetite. However, this system may override homeostatic control and cause energy imbalance (Berthoud 2011). In fact, striking similarities between food reward and drug addiction mechanisms have been reported (DiLeone et al. 2012). Therefore, these complex interactions between the homeostatic and non-homeostatic systems culminate in coordinated appetite and energy balance regulation through the modulation of endocrine, autonomic, and behavioral outputs (Fig. 2). The precise integrative mechanisms of these different levels of regulation and the generation of specific physiological outputs are among the main unsolved enigmas of the central regulation of energy balance.

\section{Declaration of interest}

The authors declare that there is no conflict of interest that could be perceived as prejudicing the impartiality of the review reported.

\section{Funding}

This work was supported by RecerCaixa grant number 2010ACUP_00275; EFSD/Lilly Fellowship Award; Ministerio de Ciencia e Innovación (MICINN), Instituto de Salud Carlos III (ISCIII) grant number PI10/01074; and MICINN grant number SAF2010-19527 (R G). M S is a recipient of an undergraduate grant from the University of Barcelona. $\mathrm{MC}$ is a recipient of a Miguel Servet contract (CP09/00233) from MICINN-ISCIII. Some of these grants are co-financed by the European Regional Development Fund 'A way to build Europe'. This work was carried out in part at the Esther Koplowitz Centre, Barcelona.

Published by Bioscientifica Ltd 


\section{References}

Abbott CR, Kennedy AR, Wren AM, Rossi M, Murphy KG, Seal LJ, Todd JF, Ghatei MA, Small CJ \& Bloom SR 2003 Identification of hypothalamic nuclei involved in the orexigenic effect of melanin-concentrating hormone. Endocrinology 144 3943-3949. (doi:10.1210/en.2003-0149)

Abbott CR, Small CJ, Kennedy AR, Neary NM, Sajedi A, Ghatei MA \& Bloom SR 2005 Blockade of the neuropeptide Y Y2 receptor with the specific antagonist BIIE0246 attenuates the effect of endogenous and exogenous peptide YY(3-36) on food intake. Brain Research 1043 139-144. (doi:10.1016/j.brainres.2005.02.065)

Adrian TE, Ferri GL, Bacarese-Hamilton AJ, Fuessl HS, Polak JM \& Bloom SR 1985 Human distribution and release of a putative new gut hormone, peptide YY. Gastroenterology 89 1070-1077.

Air EL, Benoit SC, Blake Smith KA, Clegg DJ \& Woods SC 2002 Acute third ventricular administration of insulin decreases food intake in two paradigms. Pharmacology, Biochemistry, and Behavior 72 423-429. (doi:10.1016/S0091-3057(01)00780-8)

Al-Qassab H, Smith MA, Irvine EE, Guillermet-Guibert J, Claret M, Choudhury AI, Selman C, Piipari K, Clements M, Lingard S et al. 2009 Dominant role of the $\mathrm{p} 110 \beta$ isoform of PI3K over $\mathrm{p} 110 \alpha$ in energy homeostasis regulation by POMC and AgRP neurons. Cell Metabolism 10 343-354. (doi:10.1016/j.cmet.2009.09.008)

Amar L, Benoit C, Beaumont G, Vacher CM, Crepin D, Taouis M \& Baroin-Tourancheau A 2012 MicroRNA expression profiling of hypothalamic arcuate and paraventricular nuclei from single rats using Illumina sequencing technology. Journal of Neuroscience Methods 209 134-143. (doi:10.1016/j.jneumeth.2012.05.033)

Ao Y, Go VL, Toy N, Li T, Wang Y, Song MK, Reeve JR Jr, Liu Y \& Yang H 2006 Brainstem thyrotropin-releasing hormone regulates food intake through vagal-dependent cholinergic stimulation of ghrelin secretion. Endocrinology 147 6004-6010. (doi:10.1210/en.2006-0820)

Aponte Y, Atasoy D \& Sternson SM 2011 AGRP neurons are sufficient to orchestrate feeding behavior rapidly and without training. Nature Neuroscience 14 351-355. (doi:10.1038/nn.2739)

Asnicar MA, Smith DP, Yang DD, Heiman ML, Fox N, Chen YF, Hsiung HM \& Koster A 2001 Absence of cocaine- and amphetamine-regulated transcript results in obesity in mice fed a high caloric diet. Endocrinology 142 4394-4400. (doi:10.1210/en.142.10.4394)

Atasoy D, Betley JN, Su HH \& Sternson SM 2012 Deconstruction of a neural circuit for hunger. Nature 488 172-177. (doi:10.1038/nature11270)

Bagdade JD, Bierman EL \& Porte D Jr 1967 The significance of basal insulin levels in the evaluation of the insulin response to glucose in diabetic and nondiabetic subjects. Journal of Clinical Investigation 46 1549-1557. (doi:10.1172/JCI105646)

Balthasar N, Coppari R, McMinn J, Liu SM, Lee CE, Tang V, Kenny CD, McGovern RA, Chua SC Jr, Elmquist JK et al. 2004 Leptin receptor signaling in POMC neurons is required for normal body weight homeostasis. Neuron 42 983-991. (doi:10.1016/j.neuron.2004.06.004)

Balthasar N, Dalgaard LT, Lee CE, Yu J, Funahashi H, Williams T, Ferreira M, Tang V, McGovern RA, Kenny CD et al. 2005 Divergence of melanocortin pathways in the control of food intake and energy expenditure. Cell 123 493-505. (doi:10.1016/j.cell.2005.08.035)

Banno R, Zimmer D, De Jonghe BC, Atienza M, Rak K, Yang W \& Bence KK 2010 PTP1B and SHP2 in POMC neurons reciprocally regulate energy balance in mice. Journal of Clinical Investigation 120 720-734. (doi:10.1172/JCI39620)

Barrachina MD, Martinez V, Wang L, Wei JY \& Tache Y 1997 Synergistic interaction between leptin and cholecystokinin to reduce short-term food intake in lean mice. PNAS 94 10455-10460. (doi:10.1073/pnas. 94.19.10455)

Barrera JG, Sandoval DA, D'Alessio DA \& Seeley RJ 2011 GLP-1 and energy balance: an integrated model of short-term and long-term control. Nature Reviews. Endocrinology 7 507-516. (doi:10.1038/nrendo.2011.77)
Batterham RL, Cowley MA, Small CJ, Herzog H, Cohen MA, Dakin CL, Wren AM, Brynes AE, Low MJ, Ghatei MA et al. 2002 Gut hormone PYY(3-36) physiologically inhibits food intake. Nature $\mathbf{4 1 8}$ 650-654. (doi:10.1038/nature00887)

Batterham RL, Heffron H, Kapoor S, Chivers JE, Chandarana K, Herzog H, Le Roux CW, Thomas EL, Bell JD \& Withers DJ 2006 Critical role for peptide YY in protein-mediated satiation and body-weight regulation. Cell Metabolism 4 223-233. (doi:10.1016/j.cmet.2006.08.001)

Baura GD, Foster DM, Porte D Jr, Kahn SE, Bergman RN, Cobelli C \& Schwartz MW 1993 Saturable transport of insulin from plasma into the central nervous system of dogs in vivo. A mechanism for regulated insulin delivery to the brain. Journal of Clinical Investigation 92 1824-1830. (doi:10.1172/JCI116773)

Beck B, Jhanwar-Uniyal M, Burlet A, Chapleur-Chateau M, Leibowitz SF \& Burlet C 1990 Rapid and localized alterations of neuropeptide Y in discrete hypothalamic nuclei with feeding status. Brain Research $\mathbf{5 2 8}$ 245-249. (doi:10.1016/0006-8993(90)91664-3)

Begum G, Stevens A, Smith EB, Connor K, Challis JR, Bloomfield F \& White A 2012 Epigenetic changes in fetal hypothalamic energy regulating pathways are associated with maternal undernutrition and twinning. FASEB Journal 26 1694-1703. (doi:10.1096/fj.11-198762)

Belgardt BF, Husch A, Rother E, Ernst MB, Wunderlich FT, Hampel B, Klockener T, Alessi D, Kloppenburg P \& Bruning JC 2008 PDK1 deficiency in POMC-expressing cells reveals FOXO1-dependent and -independent pathways in control of energy homeostasis and stress response. Cell Metabolism 7 291-301. (doi:10.1016/j.cmet.2008.01.006)

Benoit SC, Air EL, Coolen LM, Strauss R, Jackman A, Clegg DJ, Seeley RJ \& Woods SC 2002 The catabolic action of insulin in the brain is mediated by melanocortins. Journal of Neuroscience 22 9048-9052.

Berthoud HR 2011 Metabolic and hedonic drives in the neural control of appetite: who is the boss? Current Opinion in Neurobiology 21 888-896. (doi:10.1016/j.conb.2011.09.004)

Bewick GA, Gardiner JV, Dhillo WS, Kent AS, White NE, Webster Z, Ghatei MA $\&$ Bloom SR 2005 Post-embryonic ablation of AgRP neurons in mice leads to a lean, hypophagic phenotype. FASEB Journal 19 1680-1682. (doi:10.1096/fj.04-3434fje)

Bi S, Ladenheim EE, Schwartz GJ \& Moran TH 2001 A role for NPY overexpression in the dorsomedial hypothalamus in hyperphagia and obesity of OLETF rats. American Journal of Physiology. Regulatory, Integrative and Comparative Physiology 281 R254-R260.

Bingham NC, Anderson KK, Reuter AL, Stallings NR \& Parker KL 2008 Selective loss of leptin receptors in the ventromedial hypothalamic nucleus results in increased adiposity and a metabolic syndrome. Endocrinology 149 2138-2148. (doi:10.1210/en.2007-1200)

Blevins JE, Chelikani PK, Haver AC \& Reidelberger RD 2008 PYY(3-36) induces Fos in the arcuate nucleus and in both catecholaminergic and non-catecholaminergic neurons in the nucleus tractus solitarius of rats. Peptides 29 112-119. (doi:10.1016/j.peptides.2007.11.003)

Boey D, Lin S, Enriquez RF, Lee NJ, Slack K, Couzens M, Baldock PA, Herzog H \& Sainsbury A 2008 PYY transgenic mice are protected against dietinduced and genetic obesity. Neuropeptides 42 19-30. (doi:10.1016/ j.npep.2007.11.003)

Bolborea M \& Dale N 2013 Hypothalamic tanycytes: potential roles in the control of feeding and energy balance. Trends in Neurosciences 36 91-100. (doi:10.1016/j.tins.2012.12.008)

Broadwell RD \& Brightman MW 1976 Entry of peroxidase into neurons of the central and peripheral nervous systems from extracerebral and cerebral blood. Journal of Comparative Neurology 166 257-283. (doi:10.1002/cne. 901660302)

Broberger C, Johansen J, Johansson C, Schalling M \& Hokfelt T 1998 The neuropeptide $\mathrm{Y} /$ agouti gene-related protein (AGRP) brain circuitry in normal, anorectic, and monosodium glutamate-treated mice. PNAS 95 15043-15048. (doi:10.1073/pnas.95.25.15043)

Butler AA, Kesterson RA, Khong K, Cullen MJ, Pelleymounter MA, Dekoning J, Baetscher M \& Cone RD 2000 A unique metabolic 
syndrome causes obesity in the melanocortin-3 receptor-deficient mouse. Endocrinology 141 3518-3521. (doi:10.1210/en.141.9.3518)

Cao Y, Nakata M, Okamoto S, Takano E, Yada T, Minokoshi Y, Hirata Y, Nakajima K, Iskandar K, Hayashi Y et al. 2011 PDK1-Foxo1 in agoutirelated peptide neurons regulates energy homeostasis by modulating food intake and energy expenditure. PLOS ONE 6 e18324. (doi:10.1371/ journal.pone.0018324)

do Carmo JM, da Silva AA, Rushing JS, Pace BR \& Hall JE 2010 Differential control of metabolic and cardiovascular functions by melanocortin- 4 receptors in proopiomelanocortin neurons. American Journal of Physiology. Regulatory, Integrative and Comparative Physiology 305 R359-R368. (doi:10.1152/ajpregu.00518.2012)

Cason AM, Smith RJ, Tahsili-Fahadan P, Moorman DE, Sartor GC \& Aston-Jones G 2010 Role of orexin/hypocretin in reward-seeking and addiction: implications for obesity. Physiology \& Behavior 100 419-428. (doi:10.1016/j.physbeh.2010.03.009)

Challis BG, Pinnock SB, Coll AP, Carter RN, Dickson SL \& O'Rahilly S 2003 Acute effects of PYY3-36 on food intake and hypothalamic neuropeptide expression in the mouse. Biochemical and Biophysical Research Communications 311 915-919. (doi:10.1016/j.bbrc.2003.10.089)

Chao PT, Yang L, Aja S, Moran TH \& Bi S 2011 Knockdown of NPY expression in the dorsomedial hypothalamus promotes development of brown adipocytes and prevents diet-induced obesity. Cell Metabolism 13 573-583. (doi:10.1016/j.cmet.2011.02.019)

Chen H, Charlat O, Tartaglia LA, Woolf EA, Weng X, Ellis SJ, Lakey ND, Culpepper J, Moore KJ, Breitbart RE et al. 1996 Evidence that the diabetes gene encodes the leptin receptor: identification of a mutation in the leptin receptor gene in $d b / d b$ mice. Cell 84 491-495. (doi:10.1016/S0092-8674(00)81294-5)

Chen HY, Trumbauer ME, Chen AS, Weingarth DT, Adams JR, Frazier EG, Shen Z, Marsh DJ, Feighner SD, Guan XM et al. 2004 Orexigenic action of peripheral ghrelin is mediated by neuropeptide $\mathrm{Y}$ and agouti-related protein. Endocrinology 145 2607-2612. (doi:10.1210/en.2003-1596)

Cheung CC, Clifton DK \& Steiner RA 1997 Proopiomelanocortin neurons are direct targets for leptin in the hypothalamus. Endocrinology 138 4489-4492. (doi:10.1210/en.138.10.4489)

Cheung CC, Kurrasch DM, Liang JK \& Ingraham HA 2013 Genetic labeling of steroidogenic factor-1 (SF-1) neurons in mice reveals ventromedial nucleus of the hypothalamus (VMH) circuitry beginning at neurogenesis and development of a separate non-SF-1 neuronal cluster in the ventrolateral VMH. Journal of Comparative Neurology 521 1268-1288. (doi:10.1002/cne.23226)

Cheunsuang O \& Morris R 2005 Astrocytes in the arcuate nucleus and median eminence that take up a fluorescent dye from the circulation express leptin receptors and neuropeptide Y Y1 receptors. Glia $\mathbf{5 2}$ 228-233. (doi:10.1002/glia.20239)

Choudhury AI, Heffron H, Smith MA, Al-Qassab H, Xu AW, Selman C, Simmgen M, Clements M, Claret M, Maccoll G et al. 2005 The role of insulin receptor substrate 2 in hypothalamic and $\beta$ cell function. Journal of Clinical Investigation 115 940-950. (doi:10.1172/JCI24445)

Ciriello J, McMurray JC, Babic T \& de Oliveira CV 2003 Collateral axonal projections from hypothalamic hypocretin neurons to cardiovascular sites in nucleus ambiguus and nucleus tractus solitarius. Brain Research 991 133-141. (doi:10.1016/j.brainres.2003.08.016)

Claret M, Smith MA, Batterham RL, Selman C, Choudhury AI, Fryer LG, Clements M, Al-Qassab H, Heffron H, Xu AW et al. 2007 AMPK is essential for energy homeostasis regulation and glucose sensing by POMC and AgRP neurons. Journal of Clinical Investigation 117 2325-2336. (doi:10.1172/JCI31516)

Claret M, Smith MA, Knauf C, Al-Qassab H, Woods A, Heslegrave A, Piipari K, Emmanuel JJ, Colom A, Valet P et al. 2011 Deletion of $L k b 1$ in pro-opiomelanocortin neurons impairs peripheral glucose homeostasis in mice. Diabetes 60 735-745. (doi:10.2337/db10-1055)

Clark JT, Kalra PS, Crowley WR \& Kalra SP 1984 Neuropeptide Y and human pancreatic polypeptide stimulate feeding behavior in rats. Endocrinology 115 427-429. (doi:10.1210/endo-115-1-427)
Clement K, Vaisse C, Lahlou N, Cabrol S, Pelloux V, Cassuto D, Gourmelen M, Dina C, ChambazJ, Lacorte JM et al. 1998 A mutation in the human leptin receptor gene causes obesity and pituitary dysfunction. Nature 392 398-401. (doi:10.1038/32911)

Considine RV, Sinha MK, Heiman ML, Kriauciunas A, Stephens TW, Nyce MR, Ohannesian JP, Marco CC, McKee LJ, Bauer TL et al. 1996 Serum immunoreactive-leptin concentrations in normal-weight and obese humans. New England Journal of Medicine 334 292-295. (doi:10.1056/ NEJM199602013340503)

Contreras C, Novelle MG, Leis R, Dieguez C, Skrede S \& Lopez M 2013 Effects of neonatal programming on hypothalamic mechanisms controlling energy balance. Hormone and Metabolic Research 45 935944. (doi:10.1055/s-0033-1351281)

Corander MP, Rimmington D, Challis BG, O'Rahilly S \& Coll AP 2011 Loss of agouti-related peptide does not significantly impact the phenotype of murine POMC deficiency. Endocrinology 152 1819-1828. (doi:10.1210/en.2010-1450)

Corp ES, Woods SC, Porte D Jr, Dorsa DM, Figlewicz DP \& Baskin DG 1986 Localization of 125I-insulin binding sites in the rat hypothalamus by quantitative autoradiography. Neuroscience Letters 70 17-22. (doi:10.1016/0304-3940(86)90430-1)

Cowley MA, Smart JL, Rubinstein M, Cerdan MG, Diano S, Horvath TL, Cone RD \& Low MJ 2001 Leptin activates anorexigenic POMC neurons through a neural network in the arcuate nucleus. Nature $\mathbf{4 1 1} 480-484$. (doi:10.1038/35078085)

Cowley MA, Smith RG, Diano S, Tschop M, Pronchuk N, Grove KL, Strasburger CJ, Bidlingmaier M, Esterman M, Heiman ML et al. 2003 The distribution and mechanism of action of ghrelin in the CNS demonstrates a novel hypothalamic circuit regulating energy homeostasis. Neuron 37 649-661. (doi:10.1016/S0896-6273(03)00063-1)

Crujeiras AB, Campion J, Diaz-Lagares A, Milagro FI, Goyenechea E, Abete I, Casanueva FF \& Martinez JA 2013 Association of weight regain with specific methylation levels in the NPY and POMC promoters in leukocytes of obese men: a translational study. Regulatory Peptides $\mathbf{1 8 6}$ 1-6. (doi:10.1016/j.regpep.2013.06.012)

Cui Y, Huang L, Elefteriou F, Yang G, Shelton JM, Giles JE, Oz OK, Pourbahrami T, Lu CY, Richardson JA et al. 2004 Essential role of STAT3 in body weight and glucose homeostasis. Molecular and Cellular Biology 24 258-269. (doi:10.1128/MCB.24.1.258-269.2004)

Cyr NE, Toorie AM, Steger JS, Sochat MM, Hyner S, Perello M, Stuart R \& Nillni EA 2013 Mechanisms by which the orexigen NPY regulates anorexigenic $\alpha$-MSH and TRH. American Journal of Physiology. Endocrinology and Metabolism 304 E640-E650. (doi:10.1152/ajpendo.00448.2012)

Dagon Y, Hur E, Zheng B, Wellenstein K, Cantley LC \& Kahn BB 2012 p70S6 kinase phosphorylates AMPK on serine 491 to mediate leptin's effect on food intake. Cell Metabolism 16104-112. (doi:10.1016/j.cmet.2012.05.010)

Davis AM, Seney ML, Stallings NR, Zhao L, Parker KL \& Tobet SA 2004 Loss of steroidogenic factor 1 alters cellular topography in the mouse ventromedial nucleus of the hypothalamus. Journal of Neurobiology $\mathbf{6 0}$ 424-436. (doi:10.1002/neu.20030)

De Souza CT, Araujo EP, Bordin S, Ashimine R, Zollner RL, Boschero AC, Saad MJ \& Velloso LA 2005 Consumption of a fat-rich diet activates a proinflammatory response and induces insulin resistance in the hypothalamus. Endocrinology 146 4192-4199. (doi:10.1210/en.2004-1520)

Dietrich MO \& Horvath TL 2013 Hypothalamic control of energy balance: insights into the role of synaptic plasticity. Trends in Neurosciences 36 65-73. (doi:10.1016/j.tins.2012.12.005)

DiLeone RJ, Taylor JR \& Picciotto MR 2012 The drive to eat: comparisons and distinctions between mechanisms of food reward and drug addiction. Nature Neuroscience 15 1330-1335. (doi:10.1038/nn.3202)

Dube MG, Kalra SP \& Kalra PS 1999 Food intake elicited by central administration of orexins/hypocretins: identification of hypothalamic sites of action. Brain Research 842 473-477. (doi:10.1016/S0006-8993(99)01824-7)

Egawa M, Yoshimatsu H \& Bray GA 1991 Neuropeptide Y suppresses sympathetic activity to interscapular brown adipose tissue in rats. American Journal of Physiology 260 R328-R334. 
Elias CF, Lee C, Kelly J, Aschkenasi C, Ahima RS, Couceyro PR, Kuhar MJ Saper CB \& Elmquist JK 1998 Leptin activates hypothalamic CART neurons projecting to the spinal cord. Neuron 21 1375-1385. (doi:10.1016/S0896-6273(00)80656-X)

Elias CF, Aschkenasi C, Lee C, Kelly J, Ahima RS, Bjorbaek C, Flier JS, Saper CB \& Elmquist JK 1999 Leptin differentially regulates NPY and POMC neurons projecting to the lateral hypothalamic area. Neuron 23 775-786. (doi:10.1016/S0896-6273(01)80035-0)

Elmquist JK, Bjorbaek C, Ahima RS, Flier JS \& Saper CB 1998 Distributions of leptin receptor mRNA isoforms in the rat brain. Journal of Comparative Neurology 395 535-547. (doi:10.1002/(SICI)10969861(19980615)395:4<535::AID-CNE9>3.0.CO;2-2)

Ernst MB, Wunderlich CM, Hess S, Paehler M, Mesaros A, Koralov SB, Kleinridders A, Husch A, Munzberg H, Hampel B et al. 2009 Enhanced Stat3 activation in POMC neurons provokes negative feedback inhibition of leptin and insulin signaling in obesity. Journal of Neuroscience 29 11582-11593. (doi:10.1523/JNEUROSCI.5712-08.2009)

Fan W, Boston BA, Kesterson RA, Hruby VJ \& Cone RD 1997 Role of melanocortinergic neurons in feeding and the agouti obesity syndrome. Nature 385 165-168. (doi:10.1038/385165a0)

Fan W, Ellacott KL, Halatchev IG, Takahashi K, Yu P \& Cone RD 2004 Cholecystokinin-mediated suppression of feeding involves the brainstem melanocortin system. Nature Neuroscience 7 335-336. (doi:10.1038/nn1214)

Farooqi IS 2008 Monogenic human obesity. Frontiers of Hormone Research 36 1-11. (doi:10.1159/0000115333)

Faulconbridge LF, Cummings DE, Kaplan JM \& Grill HJ 2003 Hyperphagic effects of brainstem ghrelin administration. Diabetes 52 2260-2265. (doi:10.2337/diabetes.52.9.2260)

Fekete C, Legradi G, Mihaly E, Huang QH, Tatro JB, Rand WM, Emerson CH $\&$ Lechan RM $2000 \alpha$-Melanocyte-stimulating hormone is contained in nerve terminals innervating thyrotropin-releasing hormonesynthesizing neurons in the hypothalamic paraventricular nucleus and prevents fasting-induced suppression of prothyrotropin-releasing hormone gene expression. Journal of Neuroscience 20 1550-1558.

Fekete C, Marks DL, Sarkar S, Emerson CH, Rand WM, Cone RD \& Lechan RM 2004 Effect of agouti-related protein in regulation of the hypothalamic-pituitary-thyroid axis in the melanocortin 4 receptor knockout mouse. Endocrinology 145 4816-4821. (doi:10.1210/ en.2004-0476)

Florijn WJ, Mulder AH, Versteeg DH \& Gispen WH 1993 Adrenocorticotropin/ $\alpha$-melanocyte-stimulating hormone (ACTH/MSH)-like peptides modulate adenylate cyclase activity in rat brain slices: evidence for an ACTH/MSH receptor-coupled mechanism. Journal of Neurochemistry $\mathbf{6 0}$ 2204-2211. (doi:10.1111/j.1471-4159.1993.tb03506.x)

Frayling C, Britton R \& Dale N 2011 ATP-mediated glucosensing by hypothalamic tanycytes. Journal of Physiology 589 2275-2286. (doi:10.1113/jphysiol.2010.202051)

Fuente-Martin E, Garcia-Caceres C, Granado M, de Ceballos ML, SanchezGarrido MA, Sarman B, Liu ZW, Dietrich MO, Tena-Sempere M, Argente-Arizon P et al. 2012 Leptin regulates glutamate and glucose transporters in hypothalamic astrocytes. Journal of Clinical Investigation 122 3900-3913. (doi:10.1172/JCI64102)

Garcia-Caceres C, Fuente-Martin E, Burgos-Ramos E, Granado M, Frago LM, Barrios V, Horvath T, Argente J \& Chowen JA 2011 Differential acute and chronic effects of leptin on hypothalamic astrocyte morphology and synaptic protein levels. Endocrinology 152 1809-1818. (doi:10.1210/en.2010-1252)

Gehlert DR, Chronwall BM, Schafer MP \& O'Donohue TL 1987 Localization of neuropeptide $\mathrm{Y}$ messenger ribonucleic acid in rat and mouse brain by in situ hybridization. Synapse 1 25-31. (doi:10.1002/syn.890010106)

Gibbs J \& Smith GP 1977 Cholecystokinin and satiety in rats and rhesus monkeys. American Journal of Clinical Nutrition 30 758-761.

Gibbs J, Young RC \& Smith GP 1973 Cholecystokinin decreases food intake in rats. Journal of Comparative and Physiological Psychology 84 488-495. (doi:10.1037/h0034870)
Gil K, Bugajski A \& Thor P 2011 Electrical vagus nerve stimulation decreases food consumption and weight gain in rats fed a high-fat diet. Journal of Physiology and Pharmacology 62 637-646.

Gong L, Yao F, Hockman K, Heng HH, Morton GJ, Takeda K, Akira S, Low MJ, Rubinstein M \& MacKenzie RG 2008 Signal transducer and activator of transcription-3 is required in hypothalamic agouti-related protein/neuropeptide Y neurons for normal energy homeostasis. Endocrinology 149 3346-3354. (doi:10.1210/en.2007-0945)

Graham M, Shutter JR, Sarmiento U, Sarosi I \& Stark KL 1997 Overexpression of Agrt leads to obesity in transgenic mice. Nature Genetics 17 273-274. (doi:10.1038/ng1197-273)

Grayson BE, Levasseur PR, Williams SM, Smith MS, Marks DL \& Grove KL 2010 Changes in melanocortin expression and inflammatory pathways in fetal offspring of nonhuman primates fed a high-fat diet. Endocrinology 151 1622-1632. (doi:10.1210/en.2009-1019)

Greenman Y, Kuperman Y, Drori Y, Asa SL, Navon I, Forkosh O, Gil S, Stern N \& Chen A 2013 Postnatal ablation of POMC neurons induces an obese phenotype characterized by decreased food intake and enhanced anxiety-like behavior. Molecular Endocrinology 27 1091-1102. (doi:10.1210/me.2012-1344)

Gropp E, Shanabrough M, Borok E, Xu AW, Janoschek R, Buch T, Plum L, Balthasar N, Hampel B, Waisman A et al. 2005 Agouti-related peptideexpressing neurons are mandatory for feeding. Nature Neuroscience $\mathbf{8}$ 1289-1291. (doi:10.1038/nn1548)

Guan XM, Yu H, Trumbauer M, Frazier E, Van der Ploeg LH \& Chen H 1998 Induction of neuropeptide $\mathrm{Y}$ expression in dorsomedial hypothalamus of diet-induced obese mice. Neuroreport 9 3415-3419. (doi:10.1097/ 00001756-199810260-00015)

Guo L, Munzberg H, Stuart RC, Nillni EA \& Bjorbaek C $2004 \mathrm{~N}$-acetylation of hypothalamic $\alpha$-melanocyte-stimulating hormone and regulation by leptin. PNAS 101 11797-11802. (doi:10.1073/pnas.0403165101)

Hagan MM, Rushing PA, Pritchard LM, Schwartz MW, Strack AM, Van Der Ploeg LH, Woods SC \& Seeley RJ 2000 Long-term orexigenic effects of AgRP-(83-132) involve mechanisms other than melanocortin receptor blockade. American Journal of Physiology. Regulatory, Integrative and Comparative Physiology 279 R47-R52.

Halaas JL, Gajiwala KS, Maffei M, Cohen SL, Chait BT, Rabinowitz D, Lallone RL, Burley SK \& Friedman JM 1995 Weight-reducing effects of the plasma protein encoded by the obese gene. Science 269 543-546. (doi:10.1126/science.7624777)

Harrold JA, Widdowson PS \& Williams G 1999 Altered energy balance causes selective changes in melanocortin-4 (MC4-R), but not melanocortin-3 (MC3-R), receptors in specific hypothalamic regions: further evidence that activation of MC4-R is a physiological inhibitor of feeding. Diabetes 48 267-271. (doi:10.2337/diabetes.48.2.267)

Haskell-Luevano C \& Monck EK 2001 Agouti-related protein functions as an inverse agonist at a constitutively active brain melanocortin- 4 receptor. Regulatory Peptides 99 1-7. (doi:10.1016/S01670115(01)00234-8)

Havrankova J, Roth J \& Brownstein M 1978 Insulin receptors are widely distributed in the central nervous system of the rat. Nature $\mathbf{2 7 2}$ 827-829. (doi:10.1038/272827a0)

Hayes MR, Skibicka KP \& Grill HJ 2008 Caudal brainstem processing is sufficient for behavioral, sympathetic, and parasympathetic responses driven by peripheral and hindbrain glucagon-like-peptide-1 receptor stimulation. Endocrinology 149 4059-4068. (doi:10.1210/ en.2007-1743)

Herzer S, Silahtaroglu A \& Meister B 2012 Locked nucleic acid-based in situ hybridisation reveals miR-7a as a hypothalamus-enriched microRNA with a distinct expression pattern. Journal of Neuroendocrinology $\mathbf{2 4}$ 1492-1504. (doi:10.1111/j.1365-2826.2012.02358.x)

Hill JW, Williams KW, Ye C, Luo J, Balthasar N, Coppari R, Cowley MA, Cantley LC, Lowell BB \& Elmquist JK 2008 Acute effects of leptin require PI3K signaling in hypothalamic proopiomelanocortin neurons in mice. Journal of Clinical Investigation 118 1796-1805. (doi:10.1172/ JCI32964) 
Hill JW, Xu Y, Preitner F, Fukuda M, Cho YR, Luo J, Balthasar N, Coppari R, Cantley LC, Kahn BB et al. 2009 Phosphatidyl inositol 3-kinase signaling in hypothalamic proopiomelanocortin neurons contributes to the regulation of glucose homeostasis. Endocrinology $1504874-4882$. (doi:10.1210/en.2009-0454)

HillJW, Elias CF, Fukuda M, Williams KW, Berglund ED, Holland WL, Cho YR, Chuang JC, Xu Y, Choi M et al. 2010 Direct insulin and leptin action on pro-opiomelanocortin neurons is required for normal glucose homeostasis and fertility. Cell Metabolism 11 286-297. (doi:10.1016/ j.cmet.2010.03.002)

Horvath TL, Bechmann I, Naftolin F, Kalra SP \& Leranth C 1997 Heterogeneity in the neuropeptide Y-containing neurons of the rat arcuate nucleus: GABAergic and non-GABAergic subpopulations. Brain Research 756 283-286. (doi:10.1016/S0006-8993(97)00184-4)

Horvath TL, Sarman B, Garcia-Caceres C, Enriori PJ, Sotonyi P, Shanabrough M, Borok E, Argente J, Chowen JA, Perez-Tilve D et al. 2010 Synaptic input organization of the melanocortin system predicts diet-induced hypothalamic reactive gliosis and obesity. PNAS $\mathbf{1 0 7}$ 14875-14880. (doi:10.1073/pnas.1004282107)

Hsuchou H, He Y, Kastin AJ, Tu H, Markadakis EN, Rogers RC, Fossier PB \& Pan W 2009a Obesity induces functional astrocytic leptin receptors in hypothalamus. Brain 132 889-902. (doi:10.1093/brain/awp029)

Hsuchou H, Pan W, Barnes MJ \& Kastin AJ 2009b Leptin receptor mRNA in rat brain astrocytes. Peptides 30 2275-2280. (doi:10.1016/j.peptides. 2009.08.023)

Huszar D, Lynch CA, Fairchild-Huntress V, Dunmore JH, Fang Q, Berkemeier LR, Gu W, Kesterson RA, Boston BA, Cone RD et al. 1997 Targeted disruption of the melanocortin-4 receptor results in obesity in mice. Cell 88 131-141. (doi:10.1016/S0092-8674(00)81865-6)

Hwa JJ, Ghibaudi L, Gao J \& Parker EM 2001 Central melanocortin system modulates energy intake and expenditure of obese and lean Zucker rats. American Journal of Physiology. Regulatory, Integrative and Comparative Physiology 281 R444-R451.

Iskandar K, Cao Y, Hayashi Y, Nakata M, Takano E, Yada T, Zhang C, Ogawa W, Oki M, Chua S Jr et al. 2010 PDK-1/FoxO1 pathway in POMC neurons regulates Pomc expression and food intake. American Journal of Physiology. Endocrinology and Metabolism 298 E787-E798. (doi:10.1152/ajpendo. 00512.2009)

Jayaram B, Pan W, Wang Y, Hsuchou H, Mace A, Cornelissen-Guillaume GG, Mishra PK, Koza RA \& Kastin AJ 2013 Astrocytic leptin-receptor knockout mice show partial rescue of leptin resistance in diet-induced obesity. Journal of Applied Physiology 114 734-741. (doi:10.1152/japplphysiol. 01499.2012)

Kalra SP, Dube MG, Sahu A, Phelps CP \& Kalra PS 1991 Neuropeptide Y secretion increases in the paraventricular nucleus in association with increased appetite for food. PNAS 88 10931-10935. (doi:10.1073/pnas. 88.23.10931)

Kamegai J, Tamura H, Shimizu T, Ishii S, Sugihara H \& Wakabayashi I 2001 Chronic central infusion of ghrelin increases hypothalamic neuropeptide $\mathrm{Y}$ and agouti-related protein mRNA levels and body weight in rats. Diabetes 50 2438-2443. (doi:10.2337/diabetes.50.11.2438)

Kievit P, Howard JK, Badman MK, Balthasar N, Coppari R, Mori H, Lee CE, Elmquist JK, Yoshimura A \& Flier JS 2006 Enhanced leptin sensitivity and improved glucose homeostasis in mice lacking suppressor of cytokine signaling-3 in POMC-expressing cells. Cell Metabolism 4 123-132. (doi:10.1016/j.cmet.2006.06.010)

Kim MS, Rossi M, Abusnana S, Sunter D, Morgan DG, Small CJ, Edwards CM, Heath MM, Stanley SA, Seal LJ et al. 2000 Hypothalamic localization of the feeding effect of agouti-related peptide and $\alpha$-melanocyte-stimulating hormone. Diabetes 49 177-182. (doi:10.2337/diabetes.49.2.177)

Kim KW, Zhao L, Donato J Jr, Kohno D, Xu Y, Elias CF, Lee C, Parker KL \& Elmquist JK 2011 Steroidogenic factor 1 directs programs regulating diet-induced thermogenesis and leptin action in the ventral medial hypothalamic nucleus. PNAS 108 10673-10678. (doi:10.1073/ pnas.1102364108)
Kirchgessner AL \& Sclafani A 1988 PVN-hindbrain pathway involved in the hypothalamic hyperphagia-obesity syndrome. Physiology \& Behavior $\mathbf{4 2}$ 517-528. (doi:10.1016/0031-9384(88)90153-9)

Kishi T, Aschkenasi CJ, Lee CE, Mountjoy KG, Saper CB \& Elmquist JK 2003 Expression of melanocortin 4 receptor mRNA in the central nervous system of the rat. Journal of Comparative Neurology 457 213-235. (doi:10.1002/cne.10454)

Kissileff HR, Pi-Sunyer FX, Thornton J \& Smith GP 1981 C-terminal octapeptide of cholecystokinin decreases food intake in man. American Journal of Clinical Nutrition 34 154-160.

Kitamura T, Feng Y, Kitamura YI, Chua SC Jr, Xu AW, Barsh GS, Rossetti L \& Accili D 2006 Forkhead protein FoxO1 mediates Agrp-dependent effects of leptin on food intake. Nature Medicine 12 534-540. (doi:10.1038/nm1392)

Koda S, Date Y, Murakami N, Shimbara T, Hanada T, Toshinai K, Niijima A, Furuya M, Inomata N, Osuye K et al. 2005 The role of the vagal nerve in peripheral PYY3-36-induced feeding reduction in rats. Endocrinology 146 2369-2375. (doi:10.1210/en.2004-1266)

Kojima M, Hosoda H, Date Y, Nakazato M, Matsuo H \& Kangawa K 1999 Ghrelin is a growth-hormone-releasing acylated peptide from stomach. Nature 402 656-660. (doi:10.1038/45230)

Kong W, Stanley S, Gardiner J, Abbott C, Murphy K, Seth A, Connoley I, Ghatei M, Stephens D \& Bloom S 2003 A role for arcuate cocaine and amphetamine-regulated transcript in hyperphagia, thermogenesis, and cold adaptation. FASEB Journal 17 1688-1690. (doi:10.1096/fj.020805fje)

Kong D, Tong Q, Ye C, Koda S, Fuller PM, Krashes MJ, Vong L, Ray RS, Olson DP \& Lowell BB 2012 GABAergic RIP-Cre neurons in the arcuate nucleus selectively regulate energy expenditure. Cell 151 645-657. (doi:10.1016/ j.cell.2012.09.020)

Konner AC, Janoschek R, Plum L, Jordan SD, Rother E, Ma X, Xu C, Enriori P, Hampel B, Barsh GS et al. 2007 Insulin action in AgRP-expressing neurons is required for suppression of hepatic glucose production. Cell Metabolism 5 438-449. (doi:10.1016/j.cmet.2007.05.004)

Kotz CM, Wang CF, Briggs JE, Levine AS \& Billington CJ 2000 Effect of NPY in the hypothalamic paraventricular nucleus on uncoupling proteins 1 , 2 , and 3 in the rat. American Journal of Physiology. Regulatory, Integrative and Comparative Physiology 278 R494-R498.

Krashes MJ, Koda S, Ye C, Rogan SC, Adams AC, Cusher DS, Maratos-Flier E, Roth BL \& Lowell BB 2011 Rapid, reversible activation of AgRP neurons drives feeding behavior in mice. Journal of Clinical Investigation $\mathbf{1 2 1}$ 1424-1428. (doi:10.1172/JCI46229)

Kreymann B, Williams G, Ghatei MA \& Bloom SR 1987 Glucagon-like peptide-1 7-36: a physiological incretin in man. Lancet 2 1300-1304. (doi:10.1016/S0140-6736(87)91194-9)

Kristensen P, Judge ME, Thim L, Ribel U, Christjansen KN, Wulff BS, Clausen JT, Jensen PB, Madsen OD, Vrang N et al. 1998 Hypothalamic CART is a new anorectic peptide regulated by leptin. Nature 393 72-76. (doi:10.1038/29993)

Krolczyk G, Zurowski D, Sobocki J, Slowiaczek MP, Laskiewicz J, Matyja A, Zaraska K, Zaraska W \& Thor PJ 2001 effects of continuous microchip (MC) vagal neuromodulation on gastrointestinal function in rats. Journal of Physiology and Pharmacology 52 705-715.

Krude H, Biebermann H, Luck W, Horn R, Brabant G \& Gruters A 1998 Severe early-onset obesity, adrenal insufficiency and red hair pigmentation caused by POMC mutations in humans. Nature Genetics 19 155-157. (doi:10.1038/509)

Langlet F, Levin BE, Luquet S, Mazzone M, Messina A, Dunn-Meynell AA, Balland E, Lacombe A, Mazur D, Carmeliet P et al. 2013 Tanycytic VEGF-A boosts blood-hypothalamus barrier plasticity and access of metabolic signals to the arcuate nucleus in response to fasting. Cell Metabolism 17 607-617. (doi:10.1016/j.cmet.2013.03.004)

Lee YS, Challis BG, Thompson DA, Yeo GS, Keogh JM, Madonna ME, Wraight V, Sims M, Vatin V, Meyre D et al. 2006 A POMC variant implicates $\beta$-melanocyte-stimulating hormone in the control of human energy balance. Cell Metabolism 3 135-140. (doi:10.1016/j.cmet. 2006.01.006)

Published by Bioscientifica Ltd 
Lee M, Kim A, Chua SC Jr, Obici S \& Wardlaw SL 2007 Transgenic MSH overexpression attenuates the metabolic effects of a high-fat diet. American Journal of Physiology. Endocrinology and Metabolism 293 E121-E131. (doi:10.1152/ajpendo.00555.2006)

Lee J, Martin E, Paulino G, de Lartigue G \& Raybould HE 2011 Effect of ghrelin receptor antagonist on meal patterns in cholecystokinin type 1 receptor null mice. Physiology \& Behavior 103 181-187. (doi:10.1016/ j.physbeh.2011.01.018)

Lee DA, Bedont JL, Pak T, Wang H, Song J, Miranda-Angulo A, Takiar V, Charubhumi V, Balordi F, Takebayashi H et al. 2012 Tanycytes of the hypothalamic median eminence form a diet-responsive neurogenic niche. Nature Neuroscience 15 700-702. (doi:10.1038/nn.3079)

Li J, Tang Y \& Cai D 2012 IKK $\beta /$ NF- - B disrupts adult hypothalamic neural stem cells to mediate a neurodegenerative mechanism of dietary obesity and pre-diabetes. Nature Cell Biology 14 999-1012. (doi:10.1038/ ncb2562)

Lin HV, Plum L, Ono H, Gutierrez-Juarez R, Shanabrough M, Borok E, Horvath TL, Rossetti L \& Accili D 2010 Divergent regulation of energy expenditure and hepatic glucose production by insulin receptor in agouti-related protein and POMC neurons. Diabetes 59 337-346. (doi:10.2337/db09-1303)

Lopez M, Varela L, Vazquez MJ, Rodriguez-Cuenca S, Gonzalez CR, Velagapudi VR, Morgan DA, Schoenmakers E, Agassandian K, Lage R et al. 2010 Hypothalamic AMPK and fatty acid metabolism mediate thyroid regulation of energy balance. Nature Medicine 16 1001-1008. (doi:10.1038/nm.2207)

Ludwig DS, Tritos NA, Mastaitis JW, Kulkarni R, Kokkotou E, Elmquist J, Lowell B, Flier JS \& Maratos-Flier E 2001 Melanin-concentrating hormone overexpression in transgenic mice leads to obesity and insulin resistance. Journal of Clinical Investigation 107 379-386. (doi:10.1172/JCI10660)

Luiten PG, ter Horst GJ, Karst H \& Steffens AB 1985 The course of paraventricular hypothalamic efferents to autonomic structures in medulla and spinal cord. Brain Research 329 374-378. (doi:10.1016/ 0006-8993(85)90554-2)

Luquet S, Perez FA, Hnasko TS \& Palmiter RD 2005 NPY/AgRP neurons are essential for feeding in adult mice but can be ablated in neonates. Science 310 683-685. (doi:10.1126/science.1115524)

Luquet S, Phillips CT \& Palmiter RD 2007 NPY/AgRP neurons are not essential for feeding responses to glucoprivation. Peptides 28 214-225. (doi:10.1016/j.peptides.2006.08.036)

Lyons WE, Mamounas LA, Ricaurte GA, Coppola V, Reid SW, Bora SH, Wihler C, Koliatsos VE \& Tessarollo L 1999 Brain-derived neurotrophic factor-deficient mice develop aggressiveness and hyperphagia in conjunction with brain serotonergic abnormalities. PNAS 96 15239-15244. (doi:10.1073/pnas.96.26.15239)

Marks JL, Porte D Jr, Stahl WL \& Baskin DG 1990 Localization of insulin receptor mRNA in rat brain by in situ hybridization. Endocrinology 127 3234-3236. (doi:10.1210/endo-127-6-3234)

Marsh DJ, Weingarth DT, Novi DE, Chen HY, Trumbauer ME, Chen AS, Guan XM, Jiang MM, Feng Y, Camacho RE et al. 2002 Melaninconcentrating hormone 1 receptor-deficient mice are lean, hyperactive, and hyperphagic and have altered metabolism. PNAS 99 3240-3245. (doi:10.1073/pnas.052706899)

Martinez de Morentin PB, Whittle AJ, Ferno J, Nogueiras R, Dieguez C, Vidal-Puig A \& Lopez M 2012 Nicotine induces negative energy balance through hypothalamic AMP-activated protein kinase. Diabetes 61 807-817. (doi:10.2337/db11-1079)

McGowan MK, Andrews KM, Fenner D \& Grossman SP 1993 Chronic intrahypothalamic insulin infusion in the rat: behavioral specificity. Physiology \& Behavior 54 1031-1034. (doi:10.1016/00319384(93)90320-F)

McMahon LR \& Wellman PJ 1998 PVN infusion of GLP-1-(7-36) amide suppresses feeding but does not induce aversion or alter locomotion in rats. American Journal of Physiology 274 R23-R29.
Mercer AJ, Hentges ST, Meshul CK \& Low MJ 2013 Unraveling the central proopiomelanocortin neural circuits. Frontiers in Neuroscience $\mathbf{7} 19$. (doi:10.3389/fnins.2013.00019)

Merchenthaler I, Lane M \& Shughrue P 1999 Distribution of pre-proglucagon and glucagon-like peptide-1 receptor messenger RNAs in the rat central nervous system. Journal of Comparative Neurology $\mathbf{4 0 3}$ 261-280. (doi:10.1002/(SICI)1096-9861(19990111)403:2<261::AIDCNE8 > 3.0.CO;2-5)

Mesaros A, Koralov SB, Rother E, Wunderlich FT, Ernst MB, Barsh GS, Rajewsky K \& Bruning JC 2008 Activation of Stat3 signaling in AgRP neurons promotes locomotor activity. Cell Metabolism 7 236-248. (doi:10.1016/j.cmet.2008.01.007)

Milanski M, Degasperi G, Coope A, Morari J, Denis R, Cintra DE, Tsukumo DM, Anhe G, Amaral ME, Takahashi HK et al. 2009 Saturated fatty acids produce an inflammatory response predominantly through the activation of TLR4 signaling in hypothalamus: implications for the pathogenesis of obesity. Journal of Neuroscience $\mathbf{2 9}$ 359-370. (doi:10.1523/JNEUROSCI.2760-08.2009)

Minokoshi Y, Alquier T, Furukawa N, Kim YB, Lee A, Xue B, Mu J, Foufelle F, Ferre P, Birnbaum MJ et al. 2004 AMP-kinase regulates food intake by responding to hormonal and nutrient signals in the hypothalamus. Nature 428 569-574. (doi:10.1038/nature02440)

Mizuno TM \& Mobbs CV 1999 Hypothalamic agouti-related protein messenger ribonucleic acid is inhibited by leptin and stimulated by fasting. Endocrinology 140 814-817. (doi:10.1210/en.140.2.814)

Mizuno TM, Kleopoulos SP, Bergen HT, Roberts JL, Priest CA \& Mobbs CV 1998 Hypothalamic pro-opiomelanocortin mRNA is reduced by fasting and in $o b / o b$ and $d b / d b$ mice, but is stimulated by leptin. Diabetes $\mathbf{4 7}$ 294-297. (doi:10.2337/diab.47.2.294)

Mizuno TM, Kelley KA, Pasinetti GM, Roberts JL \& Mobbs CV 2003 Transgenic neuronal expression of proopiomelanocortin attenuates hyperphagic response to fasting and reverses metabolic impairments in leptin-deficient obese mice. Diabetes 52 2675-2683. (doi:10.2337/ diabetes.52.11.2675)

Montague CT, Farooqi IS, Whitehead JP, Soos MA, Rau H, Wareham NJ, Sewter CP, Digby JE, Mohammed SN, Hurst JA et al. 1997 Congenital leptin deficiency is associated with severe early-onset obesity in humans. Nature 387 903-908. (doi:10.1038/43185)

Moran TH, Baldessarini AR, Salorio CF, Lowery T \& Schwartz GJ 1997 Vagal afferent and efferent contributions to the inhibition of food intake by cholecystokinin. American Journal of Physiology 272 R1245-R1251.

Munzberg H, Huo L, Nillni EA, Hollenberg AN \& Bjorbaek C 2003 Role of signal transducer and activator of transcription 3 in regulation of hypothalamic proopiomelanocortin gene expression by leptin. Endocrinology 144 2121-2131. (doi:10.1210/en.2002-221037)

Nakazato M, Murakami N, Date Y, Kojima M, Matsuo H, Kangawa K \& Matsukura S 2001 A role for ghrelin in the central regulation of feeding. Nature 409 194-198. (doi:10.1038/35051587)

Naleid AM, Grace MK, Cummings DE \& Levine AS 2005 Ghrelin induces feeding in the mesolimbic reward pathway between the ventral tegmental area and the nucleus accumbens. Peptides 26 2274-2279. (doi:10.1016/j.peptides.2005.04.025)

Nguyen AD, Mitchell NF, Lin S, Macia L, Yulyaningsih E, Baldock PA, Enriquez RF, Zhang L, Shi YC, Zolotukhin S et al. 2012 Y1 and Y5 receptors are both required for the regulation of food intake and energy homeostasis in mice. PLoS ONE 7 e40191. (doi:10.1371/journal.pone. 0040191)

Nijenhuis WA, Oosterom J \& Adan RA $2001 \operatorname{AgRP}(83-132)$ acts as an inverse agonist on the human-melanocortin-4 receptor. Molecular Endocrinology 15 164-171. (doi:10.1210/me.15.1.164)

Ollmann MM, Wilson BD, Yang YK, Kerns JA, Chen Y, Gantz I \& Barsh GS 1997 Antagonism of central melanocortin receptors in vitro and in vivo by agouti-related protein. Science 278 135-138. (doi:10.1126/science. 278.5335.135)

Olofsson LE, Unger EK, Cheung CC \& Xu AW 2013 Modulation of AgRPneuronal function by SOCS3 as an initiating event in diet-induced 
hypothalamic leptin resistance. PNAS 110 E697-E706. (doi:10.1073/ pnas.1218284110)

Palkovits M \& Eskay RL 1987 Distribution and possible origin of $\beta$ endorphin and ACTH in discrete brainstem nuclei of rats. Neuropeptides 9 123-137. (doi:10.1016/0143-4179(87)90051-5)

Palmiter RD, Erickson JC, Hollopeter G, Baraban SC \& Schwartz MW 1998 Life without neuropeptide Y. Recent Progress in Hormone Research $\mathbf{5 3}$ 163-199.

Parise EM, Lilly N, Kay K, Dossat AM, Seth R, Overton JM \& Williams DL 2011 Evidence for the role of hindbrain orexin-1 receptors in the control of meal size. American Journal of Physiology. Regulatory, Integrative and Comparative Physiology 301 R1692-R1699. (doi:10.1152/ajpregu. 00044.2011)

Parker KL, Rice DA, Lala DS, Ikeda Y, Luo X, Wong M, Bakke M, Zhao L, Frigeri C, Hanley NA et al. 2002 Steroidogenic factor 1: an essential mediator of endocrine development. Recent Progress in Hormone Research 57 19-36. (doi:10.1210/rp.57.1.19)

Paternain L, Batlle MA, De la Garza AL, Milagro FI, Martinez JA \& Campion J 2012 Transcriptomic and epigenetic changes in the hypothalamus are involved in an increased susceptibility to a high-fat-sucrose diet in prenatally stressed female rats. Neuroendocrinology 96 249-260. (doi:10.1159/000341684)

Peyron C, Tighe DK, van den Pol AN, de Lecea L, Heller HC, Sutcliffe JG \& Kilduff TS 1998 Neurons containing hypocretin (orexin) project to multiple neuronal systems. Journal of Neuroscience 18 9996-10015.

Pinto S, Roseberry AG, Liu H, Diano S, Shanabrough M, Cai X, Friedman JM \& Horvath TL 2004 Rapid rewiring of arcuate nucleus feeding circuits by leptin. Science 304 110-115. (doi:10.1126/science.1089459)

Plagemann A, Harder T, Brunn M, Harder A, Roepke K, Wittrock-Staar M, Ziska T, Schellong K, Rodekamp E, Melchior K et al. 2009 Hypothalamic proopiomelanocortin promoter methylation becomes altered by early overfeeding: an epigenetic model of obesity and the metabolic syndrome. Journal of Physiology $\mathbf{5 8 7}$ 4963-4976. (doi:10.1113/jphysiol.2009.176156)

Plagemann A, Roepke K, Harder T, Brunn M, Harder A, Wittrock-Staar M, Ziska T, Schellong K, Rodekamp E, Melchior K et al. 2010 Epigenetic malprogramming of the insulin receptor promoter due to developmental overfeeding. Journal of Perinatal Medicine 38 393-400. (doi:10.1515/jpm.2010.051)

Plum L, Lin HV, Dutia R, Tanaka J, Aizawa KS, Matsumoto M, Kim AJ, Cawley NX, Paik JH, Loh YP et al. 2009 The obesity susceptibility gene Cpe links FoxO1 signaling in hypothalamic pro-opiomelanocortin neurons with regulation of food intake. Nature Medicine 15 1195-1201. (doi:10.1038/nm.2026)

Poggioli R, Vergoni AV \& Bertolini A 1986 ACTH-(1-24) and $\alpha$-MSH antagonize feeding behavior stimulated by kappa opiate agonists. Peptides 7 843-848. (doi:10.1016/0196-9781(86)90104-X)

van den Pol AN, Yao Y, Fu LY, Foo K, Huang H, Coppari R, Lowell BB \& Broberger C 2009 Neuromedin B and gastrin-releasing peptide excite arcuate nucleus neuropeptide $\mathrm{Y}$ neurons in a novel transgenic mouse expressing strong Renilla green fluorescent protein in NPY neurons. Journal of Neuroscience 29 4622-4639. (doi:10.1523/JNEUROSCI.3249. 08.2009)

Qian S, Chen H, Weingarth D, Trumbauer ME, Novi DE, Guan X, Yu H, Shen Z, Feng Y, Frazier E et al. 2002 Neither agouti-related protein nor neuropeptide $\mathrm{Y}$ is critically required for the regulation of energy homeostasis in mice. Molecular and Cellular Biology 22 5027-5035. (doi:10.1128/MCB.22.14.5027-5035.2002)

Qiu J, Fang Y, Ronnekleiv OK \& Kelly MJ 2010 Leptin excites proopiomelanocortin neurons via activation of TRPC channels. Journal of Neuroscience 30 1560-1565. (doi:10.1523/JNEUROSCI.4816-09.2010)

Qu D, Ludwig DS, Gammeltoft S, Piper M, Pelleymounter MA, Cullen MJ, Mathes WF, Przypek R, Kanarek R \& Maratos-Flier E 1996 A role for melanin-concentrating hormone in the central regulation of feeding behaviour. Nature 380 243-247. (doi:10.1038/380243a0)

Reed AS, Unger EK, Olofsson LE, Piper ML, Myers MG Jr \& Xu AW 2010 Functional role of suppressor of cytokine signaling 3 upregulation in hypothalamic leptin resistance and long-term energy homeostasis. Diabetes 59 894-906. (doi:10.2337/db09-1024)

Ren H, Orozco IJ, Su Y, Suyama S, Gutierrez-Juarez R, Horvath TL, Wardlaw SL, Plum L, Arancio O \& Accili D 2012 FoxO1 target Gpr17 activates AgRP neurons to regulate food intake. Cell 149 1314-1326. (doi:10.1016/ j.cell.2012.04.032)

Richard D \& Baraboi D 2004 Circuitries involved in the control of energy homeostasis and the hypothalamic-pituitary-adrenal axis activity. Treatments in Endocrinology 3 269-277. (doi:10.2165/00024677200403050-00001)

Robertson SA, Leinninger GM \& Myers MG Jr 2008 Molecular and neural mediators of leptin action. Physiology \& Behavior 94 637-642. (doi:10.1016/j.physbeh.2008.04.005)

Roseberry AG, Liu H, Jackson AC, Cai X \& Friedman JM 2004 Neuropeptide Y-mediated inhibition of proopiomelanocortin neurons in the arcuate nucleus shows enhanced desensitization in $o b / o b$ mice. Neuron $\mathbf{4 1}$ 711-722. (doi:10.1016/S0896-6273(04)00074-1)

Rossi J, Balthasar N, Olson D, Scott M, Berglund E, Lee CE, Choi MJ, Lauzon D, Lowell BB \& Elmquist JK 2011 Melanocortin-4 receptors expressed by cholinergic neurons regulate energy balance and glucose homeostasis. Cell Metabolism 13 195-204. (doi:10.1016/j.cmet.2011.01.010)

Rother E, Belgardt BF, Tsaousidou E, Hampel B, Waisman A, Myers MG Jr \& Bruning JC 2012 Acute selective ablation of rat insulin promoterexpressing (RIPHER) neurons defines their orexigenic nature. PNAS 109 18132-18137. (doi:10.1073/pnas.1206147109)

Sakurai T, Amemiya A, Ishii M, Matsuzaki I, Chemelli RM, Tanaka H, Williams SC, Richardson JA, Kozlowski GP, Wilson S et al. 1998 Orexins and orexin receptors: a family of hypothalamic neuropeptides and $\mathrm{G}$ protein-coupled receptors that regulate feeding behavior. Cell 92 573-585. (doi:10.1016/S0092-8674(00)80949-6)

Savontaus E, Breen TL, Kim A, Yang LM, Chua SC Jr \& Wardlaw SL 2004 Metabolic effects of transgenic melanocyte-stimulating hormone overexpression in lean and obese mice. Endocrinology 145 3881-3891. (doi:10.1210/en.2004-0263)

Sawchenko PE \& Swanson LW 1982 Immunohistochemical identification of neurons in the paraventricular nucleus of the hypothalamus that project to the medulla or to the spinal cord in the rat. Journal of Comparative Neurology 205 260-272. (doi:10.1002/cne.902050306)

Schneeberger M, Altirriba J, Garcia A, Esteban Y, Castaño C, GarciaLavandeira M, Alvarez CV, Gomis R \& Claret M 2013 Deletion of miRNA processing enzyme Dicer in POMC-expressing cells leads to pituitary dysfunction, neurodegeneration and development of obesity. Molecular Metabolism 2 74-85. (doi:10.1016/j.molmet.2012.10.001)

Schwartz MW, Sipols AJ, Marks JL, Sanacora G, White JD, Scheurink A, Kahn SE, Baskin DG, Woods SC, Figlewicz DP et al. 1992 Inhibition of hypothalamic neuropeptide Y gene expression by insulin. Endocrinology 130 3608-3616. (doi:10.1210/en.130.6.3608)

Schwartz MW, Baskin DG, Bukowski TR, Kuijper JL, Foster D, Lasser G, Prunkard DE, Porte D Jr, Woods SC, Seeley RJ et al. 1996 Specificity of leptin action on elevated blood glucose levels and hypothalamic neuropeptide Y gene expression in ob/ob mice. Diabetes 45 531-535. (doi:10.2337/diab.45.4.531)

Schwartz MW, Seeley RJ, Woods SC, Weigle DS, Campfield LA, Burn P \& Baskin DG 1997 Leptin increases hypothalamic pro-opiomelanocortin mRNA expression in the rostral arcuate nucleus. Diabetes $\mathbf{4 6}$ 2119-2123. (doi:10.2337/diab.46.12.2119)

Schwartz GJ, Salorio CF, Skoglund C \& Moran TH 1999 Gut vagal afferent lesions increase meal size but do not block gastric preload-induced feeding suppression. American Journal of Physiology 276 R1623-R1629.

Scott V, Kimura N, Stark JA \& Luckman SM 2005 Intravenous peptide YY3-36 and Y2 receptor antagonism in the rat: effects on feeding behaviour. Journal of Neuroendocrinology 17 452-457. (doi:10.1111/ j.1365-2826.2005.01330.x)

Segal JP, Stallings NR, Lee CE, Zhao L, Socci N, Viale A, Harris TM, Soares MB, Childs G, Elmquist JK et al. 2005 Use of laser-capture microdissection for the identification of marker genes for the ventromedial hypothalamic 
nucleus. Journal of Neuroscience 25 4181-4188. (doi:10.1523/JNEUROSCI. 0158-05.2005)

Shi YC, Lau J, Lin Z, Zhang H, Zhai L, Sperk G, Heilbronn R, Mietzsch M, Weger S, Huang XF et al. 2013 Arcuate NPY controls sympathetic output and BAT function via a relay of tyrosine hydroxylase neurons in the PVN. Cell Metabolism 17 236-248. (doi:10.1016/j.cmet.2013.01.006)

Sipols AJ, Baskin DG \& Schwartz MW 1995 Effect of intracerebroventricular insulin infusion on diabetic hyperphagia and hypothalamic neuropeptide gene expression. Diabetes 44 147-151. (doi:10.2337/ diab.44.2.147)

Skibicka KP \& Grill HJ 2009a Hindbrain leptin stimulation induces anorexia and hyperthermia mediated by hindbrain melanocortin receptors. Endocrinology 150 1705-1711. (doi:10.1210/en.2008-1316)

Skibicka KP \& Grill HJ 2009b Hypothalamic and hindbrain melanocortin receptors contribute to the feeding, thermogenic, and cardiovascular action of melanocortins. Endocrinology 150 5351-5361. (doi:10.1210/ en.2009-0804)

Small CJ, Liu YL, Stanley SA, Connoley IP, Kennedy A, Stock MJ \& Bloom SR 2003 Chronic CNS administration of agouti-related protein (Agrp) reduces energy expenditure. International Journal of Obesity and Related Metabolic Disorders 27 530-533. (doi:10.1038/sj.ijo.0802253)

Smart JL, Tolle V \& Low MJ 2006 Glucocorticoids exacerbate obesity and insulin resistance in neuron-specific proopiomelanocortin-deficient mice. Journal of Clinical Investigation 116 495-505. (doi:10.1172/ JCI25243)

Smith MA, Hisadome K, Al-Qassab H, Heffron H, Withers DJ \& Ashford ML 2007 Melanocortins and agouti-related protein modulate the excitability of two arcuate nucleus neuron populations by alteration of resting potassium conductances. Journal of Physiology $\mathbf{5 7 8} 425-438$. (doi:10.1113/jphysiol.2006.119479)

Sofroniew MV \& Vinters HV 2010 Astrocytes: biology and pathology. Acta Neuropathologica 119 7-35. (doi:10.1007/s00401-009-0619-8)

Sohn JW, Elmquist JK \& Williams KW 2013 Neuronal circuits that regulate feeding behavior and metabolism. Trends in Neurosciences 36 504-512. (doi:10.1016/j.tins.2013.05.003)

Stanley BG, Kyrkouli SE, Lampert S \& Leibowitz SF 1986 Neuropeptide Y chronically injected into the hypothalamus: a powerful neurochemical inducer of hyperphagia and obesity. Peptides 7 1189-1192. (doi:10.1016/0196-9781(86)90149-X)

Stephens TW, Basinski M, Bristow PK, Bue-Valleskey JM, Burgett SG, Craft L, Hale J, Hoffmann J, Hsiung HM, Kriauciunas A et al. 1995 The role of neuropeptide $\mathrm{Y}$ in the antiobesity action of the obese gene product. Nature 377 530-532. (doi:10.1038/377530a0)

Sternson SM 2013 Hypothalamic survival circuits: blueprints for purposive behaviors. Neuron 77 810-824. (doi:10.1016/j.neuron.2013.02.018)

Stevens A, Begum G, Cook A, Connor K, Rumball C, Oliver M, Challis J, Bloomfield F \& White A 2010 Epigenetic changes in the hypothalamic proopiomelanocortin and glucocorticoid receptor genes in the ovine fetus after periconceptional undernutrition. Endocrinology 151 3652-3664. (doi:10.1210/en.2010-0094)

Sun Y, Wang P, Zheng H \& Smith RG 2004 Ghrelin stimulation of growth hormone release and appetite is mediated through the growth hormone secretagogue receptor. PNAS 101 4679-4684. (doi:10.1073/ pnas.0305930101)

Tang-Christensen M, Larsen PJ, Goke R, Fink-Jensen A, Jessop DS, Moller M \& Sheikh SP 1996 Central administration of GLP-1-(7-36) amide inhibits food and water intake in rats. American Journal of Physiology 271 R848-R856.

Tapia-Gonzalez S, Garcia-Segura LM, Tena-Sempere M, Frago LM, Castellano JM, Fuente-Martin E, Garcia-Caceres C, Argente J \& Chowen JA 2011 Activation of microglia in specific hypothalamic nuclei and the cerebellum of adult rats exposed to neonatal overnutrition. Journal of Neuroendocrinology 23 365-370. (doi:10.1111/j.1365-2826.2011.02113.x) Tatemoto K \& Mutt V 1980 Isolation of two novel candidate hormones using a chemical method for finding naturally occurring polypeptides. Nature 285 417-418. (doi:10.1038/285417a0)
Thaler JP, Choi SJ, Schwartz MW \& Wisse BE 2010 Hypothalamic inflammation and energy homeostasis: resolving the paradox. Frontiers in Neuroendocrinology 31 79-84. (doi:10.1016/j.yfrne.2009.10.002)

Thaler JP, Yi CX, Schur EA, Guyenet SJ, Hwang BH, Dietrich MO, Zhao X, Sarruf DA, Izgur V, Maravilla KR et al. 2012 Obesity is associated with hypothalamic injury in rodents and humans. Journal of Clinical Investigation 122 153-162. (doi:10.1172/JCI59660)

Thornton JE, Cheung CC, Clifton DK \& Steiner RA 1997 Regulation of hypothalamic proopiomelanocortin mRNA by leptin in $o b / o b$ mice. Endocrinology 138 5063-5066. (doi:10.1210/en.138.11.5063)

Tolle V \& Low MJ 2008 In vivo evidence for inverse agonism of agoutirelated peptide in the central nervous system of proopiomelanocortindeficient mice. Diabetes 57 86-94. (doi:10.2337/db07-0733)

Tong Q, Ye CP, Jones JE, Elmquist JK \& Lowell BB 2008 Synaptic release of GABA by AgRP neurons is required for normal regulation of energy balance. Nature Neuroscience 11 998-1000. (doi:10.1038/nn.2167)

van den Top M, Lee K, Whyment AD, Blanks AM \& Spanswick D 2004 Orexigen-sensitive NPY/AgRP pacemaker neurons in the hypothalamic arcuate nucleus. Nature Neuroscience 7 493-494. (doi:10.1038/nn1226)

Travagli RA, Hermann GE, Browning KN \& Rogers RC 2006 Brainstem circuits regulating gastric function. Annual Review of Physiology $\mathbf{6 8}$ 279-305. (doi:10.1146/annurev.physiol.68.040504.094635)

Tschop M, Smiley DL \& Heiman ML 2000 Ghrelin induces adiposity in rodents. Nature $\mathbf{4 0 7}$ 908-913. (doi:10.1038/35038090)

Turton MD, O'Shea D, Gunn I, Beak SA, Edwards CM, Meeran K, Choi SJ, Taylor GM, Heath MM, Lambert PD et al. 1996 A role for glucagon-like peptide-1 in the central regulation of feeding. Nature 379 69-72. (doi:10.1038/379069a0)

Vong L, Ye C, Yang Z, Choi B, Chua S Jr \& Lowell BB 2011 Leptin action on GABAergic neurons prevents obesity and reduces inhibitory tone to POMC neurons. Neuron 71 142-154. (doi:10.1016/j.neuron.2011. 05.028)

van de Wall E, Leshan R, Xu AW, Balthasar N, Coppari R, Liu SM, Jo YH, MacKenzie RG, Allison DB, Dun NJ et al. 2008 Collective and individual functions of leptin receptor modulated neurons controlling metabolism and ingestion. Endocrinology 149 1773-1785. (doi:10.1210/ en.2007-1132)

Whittle AJ, Carobbio S, Martins L, Slawik M, Hondares E, Vazquez MJ, Morgan D, Csikasz RI, Gallego R, Rodriguez-Cuenca S et al. 2012 BMP8B increases brown adipose tissue thermogenesis through both central and peripheral actions. Cell 149 871-885. (doi:10.1016/j.cell.2012.02.066)

Willesen MG, Kristensen P \& Romer J 1999 Co-localization of growth hormone secretagogue receptor and NPY mRNA in the arcuate nucleus of the rat. Neuroendocrinology 70 306-316. (doi:10.1159/000054491)

Williams DL, Kaplan JM \& Grill HJ 2000 The role of the dorsal vagal complex and the vagus nerve in feeding effects of melanocortin-3/4 receptor stimulation. Endocrinology 141 1332-1337. (doi:10.1210/ en.141.4.1332)

Wirth MM, Olszewski PK, Yu C, Levine AS \& Giraudo SQ 2001 Paraventricular hypothalamic $\alpha$-melanocyte-stimulating hormone and MTII reduce feeding without causing aversive effects. Peptides 22 129-134. (doi:10.1016/S0196-9781(00)00367-3)

Woods SC, Lotter EC, McKay LD \& Porte D Jr 1979 Chronic intracerebroventricular infusion of insulin reduces food intake and body weight of baboons. Nature 282 503-505. (doi:10.1038/282503a0)

Wren AM, Seal LJ, Cohen MA, Brynes AE, Frost GS, Murphy KG, Dhillo WS, Ghatei MA \& Bloom SR 2001 Ghrelin enhances appetite and increases food intake in humans. Journal of Clinical Endocrinology and Metabolism 86 5992. (doi:10.1210/jc.86.12.5992)

Wu Q \& Palmiter RD 2011 GABAergic signaling by AgRP neurons prevents anorexia via a melanocortin-independent mechanism. European Journal of Pharmacology 660 21-27. (doi:10.1016/j.ejphar.2010.10.110)

Wu Q, Boyle MP \& Palmiter RD 2009 Loss of GABAergic signaling by AgRP neurons to the parabrachial nucleus leads to starvation. Cell $\mathbf{1 3 7}$ 1225-1234. (doi:10.1016/j.cell.2009.04.022) 
Wu Q, Clark MS \& Palmiter RD 2012 Deciphering a neuronal circuit that mediates appetite. Nature 483 594-597. (doi:10.1038/nature10899)

Xu B, Goulding EH, Zang K, Cepoi D, Cone RD, Jones KR, Tecott LH \& Reichardt LF 2003 Brain-derived neurotrophic factor regulates energy balance downstream of melanocortin-4 receptor. Nature Neuroscience 6 736-742. (doi:10.1038/nn1073)

Xu AW, Kaelin CB, Morton GJ, Ogimoto K, Stanhope K, Graham J, Baskin DG, Havel P, Schwartz MW \& Barsh GS 2005a Effects of hypothalamic neurodegeneration on energy balance. PLoS Biology 3 e415. (doi:10.1371/ journal.pbio.0030415)

Xu AW, Kaelin CB, Takeda K, Akira S, Schwartz MW \& Barsh GS 2005b PI3K integrates the action of insulin and leptin on hypothalamic neurons. Journal of Clinical Investigation 115 951-958. (doi:10.1172/JCI24301)

Xu AW, Ste-Marie L, Kaelin CB \& Barsh GS 2007 Inactivation of signal transducer and activator of transcription 3 in proopiomelanocortin (Pomc) neurons causes decreased pomc expression, mild obesity, and defects in compensatory refeeding. Endocrinology 148 72-80. (doi:10.1210/en.2006-1119)

Yang Y, Atasoy D, Su HH \& Sternson SM 2011 Hunger states switch a flipflop memory circuit via a synaptic AMPK-dependent positive feedback loop. Cell 146 992-1003. (doi:10.1016/j.cell.2011.07.039)

Yaswen L, Diehl N, Brennan MB \& Hochgeschwender U 1999 Obesity in the mouse model of pro-opiomelanocortin deficiency responds to peripheral melanocortin. Nature Medicine 5 1066-1070. (doi:10.1038/12506)

Yeo GS, Connie Hung CC, Rochford J, Keogh J, Gray J, Sivaramakrishnan S, O'Rahilly S \& Farooqi IS 2004 A de novo mutation affecting human TrkB associated with severe obesity and developmental delay. Nature Neuroscience 7 1187-1189. (doi:10.1038/nn1336)
Yi CX, Al-Massadi O, Donelan E, Lehti M, Weber J, Ress C, Trivedi C, Muller TD, Woods SC \& Hofmann SM 2012 Exercise protects against high-fat diet-induced hypothalamic inflammation. Physiology \& Behavior 106 485-490. (doi:10.1016/j.physbeh.2012.03.021)

Zeltser LM, Seeley RJ \& Tschop MH 2012 Synaptic plasticity in neuronal circuits regulating energy balance. Nature Neuroscience 15 1336-1342. (doi:10.1038/nn.3219)

Zhan C, Zhou J, Feng Q, Zhang JE, Lin S, Bao J, Wu P \& Luo M 2013 Acute and long-term suppression of feeding behavior by POMC neurons in the brainstem and hypothalamus, respectively. Journal of Neuroscience 33 3624-3632. (doi:10.1523/JNEUROSCI.2742-12.2013)

Zhang Y, Proenca R, Maffei M, Barone M, Leopold L \& Friedman JM 1994 Positional cloning of the mouse obese gene and its human homologue. Nature 372 425-432. (doi:10.1038/372425a0)

Zhang R, Dhillon H, Yin H, Yoshimura A, Lowell BB, Maratos-Flier E \& Flier JS 2008 Selective inactivation of Socs 3 in SF1 neurons improves glucose homeostasis without affecting body weight. Endocrinology 149 5654-5661. (doi:10.1210/en.2008-0805)

Zhao K, Ao Y, Harper RM, Go VL \& Yang H 2013 Food-intake dysregulation in type 2 diabetic Goto-Kakizaki rats: hypothesized role of dysfunctional brainstem thyrotropin-releasing hormone and impaired vagal output. Neuroscience 247 43-54. (doi:10.1016/j.neuroscience. 2013.05.017)

Zheng H, Patterson LM, Rhodes CJ, Louis GW, Skibicka KP, Grill HJ, Myers MG Jr \& Berthoud HR 2010 A potential role for hypothalamomedullary POMC projections in leptin-induced suppression of food intake. American Journal of Physiology. Regulatory, Integrative and Comparative Physiology 298 R720-R728. (doi:10.1152/ajpregu.00619.2009)

Received in final form 29 October 2013 Accepted 7 November 2013
C 2014 Society for Endocrinology Printed in Great Britain
Published by Bioscientifica Ltd 